\title{
Non-Quantal Acetylcholine Release at the Neuromuscular Junction
}

\author{
F. VYSKOČIL ${ }^{1,2}$, A. I. MALOMOUZH ${ }^{3}$, E. E. NIKOLSKY ${ }^{3}$ \\ ${ }^{1}$ Institute of Physiology, Czech Academy of Sciences, Prague, ${ }^{2}$ Department of Animal Physiology \\ and Developmental Biology, Faculty of Science, Charles University, Prague, Czech Republic, \\ ${ }^{3}$ Institute of Biochemistry and Biophysics, Russian Academy of Sciences and Kazan State Medical \\ University, Kazan, Russia
}

Received July 23, 2009

Accepted August 27, 2009

\section{Summary}

There are two principal mechanisms of acetylcholine (ACh) release from the resting motor nerve terminal: quantal and nonquantal (NQR); the former being only a small fraction of the total, at least at rest. In the present article we summarize basic research about the NQR that is undoubtedly an important trophic factor during endplate development and in adult neuromuscular contacts. NQR helps to eliminate the polyneural innervation of developing muscle fibers, ensures higher excitability of the adult subsynaptic membrane by surplus polarization and protects the RMP from depolarization by regulating the NO cascade and chloride transport. It shortens the endplate potentials by promoting postsynaptic receptor desensitization when AChE is inhibited during anti-AChE poisoning. In adult synapses, it can also activate the electrogenic $\mathrm{Na}^{+} / \mathrm{K}^{+}$-pump, change the degree of synchronization of quanta released by the nerve stimulation and affects the contractility of skeletal muscles.

\section{Key words}

Acetylcholine - Non-quantal release - Neuromuscular junction • Synapse development • Nitric oxide • Desensitization • Resting membrane potential - Hibernation - Choline transporter • Vesicular ACh transporter • Anticholinesterase • $\mathrm{N}$-acetylaspartylglutamate $\bullet$ Miniature endplate potential

\section{Corresponding author}

F. Vyskočil, Institute of Physiology, Czech Academy of Sciences, Vídeňská 1083, 14220 Prague, Czech Republic. E-mail: vyskocil@biomed.cas.cz

\section{Introduction}

It is generally accepted that the transmission of excitation from motor nerves to the skeletal muscles occurs via release of relatively stable portions of chemical substance - quanta of neurotransmitter.

In vertebrates, from several dozens (synapses of warm-blooded animals) to a few hundred (synapses of cold-blooded animals) quanta of acetylcholine (ACh) are released following stimulation of motor nerve endings (for review Slater 2008). The acetylcholine activates postsynaptic receptors, an excitatory end-plate potential develops and ultimately a contraction may be launched. Endplate potentials resulting from the release of single quantum do not reach the threshold of excitation of muscle fibers, and are called miniature endplate potentials (MEPPs). At rest, without any nerve stimulation, a spontaneous release of individual quanta may be observed.

However, in the 1970s, the founder of quantum hypothesis of neurosecretion Katz and Miledi (1977) and independently Vyskočil and Illés (1977) suggested an alternative pathway of release of $\mathrm{ACh}$ from the cytoplasmic pool into synaptic cleft - the process of non-quantal release (NQR). This process can be influenced by many physical, biochemical and pharmacological conditions and therefore it cannot be considered to be a simple non-specific leakage.

The purpose of this review is to describe the progress that has been made in defining and understanding the phenomenon of NQR and to stress some functional roles of this type of release, as based on 
our own data and other observations.

\section{Early observations}

The first evidence that a neuromuscular preparation is able to release acetylcholine into the surrounding solution in a non-quantum manner was obtained by Mitchell and Silver (1963) as well as by Fletcher and Forrester (1975). The release of ACh from an isolated diaphragm neuromuscular preparation treated with an anti-cholinesterase (anti-AChE) estimated by available biochemical methods far exceeded the amount that could be accounted for by the quantal release due to spontaneous MEPPs (Mitchell and Silver 1963, Fletcher and Forrester 1975). Depolarization of the nerve and muscle by $8-14 \mathrm{mM} \mathrm{K}^{+}$increased both the total and quantal releases, but to different degrees. It was also found that stimulation at $2 \mathrm{~Hz}$ increased the total release 1.4-fold but the quantal release 45-fold (Vizi and Vyskočil 1979). Therefore the major part of the resting release must derive from the axon, the nerve terminal or the muscle. Experiments with denervated muscles (Zemková et al. 1987, Nikolsky et al. 1996) confirmed that the nerve terminal was the main, however not the only source, of the ACh (Krnjevic and Straughan 1964, Potter 1970, Doležal and Tuček 1983, 1992).

Taking into account the frequency of spontaneous quantum release (about 1 quanta per second), the number of $\mathrm{ACh}$ molecules in the quantum (about 10 000) (Kuffler and Yoshikami 1975) and the number of synapses in the studied muscle, it was concluded that only a few percent of the ACh released at rest was due to spontaneous quantal secretion. It was shown that muscle $\mathrm{ACh}$ is synthesized with the participation of two different enzymes: choline acetyltransferase (EC 2.3.1.6) and carnitine acetyltransferase (EC 2.3.1.7). They differ by localization in muscle, by pharmacological properties and sensitivity to denervation (Molenaar and Polak 1980, Tuček 1982). The physiological reason of the release of the ACh from muscle fibers is yet to be resolved and is beyond the scope of this review. But what is important, is that approximately $50 \%$ of $\mathrm{ACh}$ released at rest is not from either the muscle or in quanta leaving the nerve terminal and this portion of transmitter should thus be viewed as being released non-quantally. By another words, there are two principal mechanisms of release from the resting motor nerve terminal: quantal and non-quantal, or vesicular and non-vesicular and the former is only a small fraction of the total (Vyskočil 2003), at least at rest.

The concept of NQR (Vyskočil et al. 1989), could explain the phenomenon described by Douglas and Paton (1954) a half-century ago. They observed marked depolarization of the endplate zone of the cat gracilis muscle of several $\mathrm{mV}$ after injection of an anti-AChE into the jugular vein. Extracellular records of the potential along a muscle produced by traversing the muscle in a paraffin bath with a scanning electrode showed the depolarization to develop as soon as 70-80 s after antiAChE treatment (Fig. 1A) and to be absent after denervation. This depolarization was not accompanied by muscle twitching which seems to exclude the participation of action potentials in the nerve terminal or increased quantal release.

These findings apparently represent the first electrophysiological evidence for what we now call the NQR of ACh from nerve terminals. Douglas and Paton (1954) cautiously stated that ,...there is no evidence excluding the possibility that anti-AChE provokes a slow output of acetylcholine from the motor nerve“.

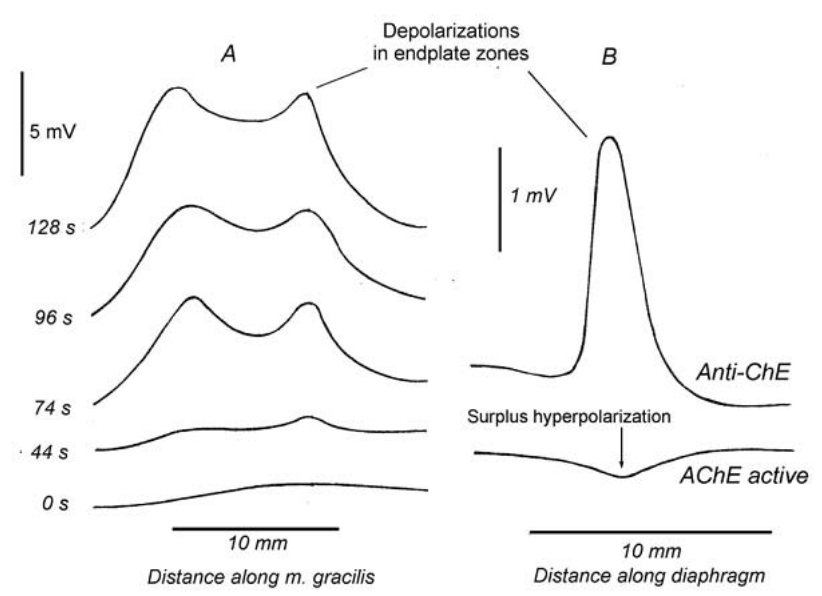

Fig. 1. Distribution of potential along the cat gracilis muscle ( $m$. gracilis, A) and mouse hemidiaphragm (B). In A, the control tracing was taken at zero time, after which the anticholinesterase, tetraethylpyrophosphate $(560 \mathrm{mg} / \mathrm{kg})$, was injected into the jugular vein. The distribution of the electrical potential along the length of the muscle was measured by traversing the muscle in a paraffin bath with a scanning electrode (modified from Douglas and Paton 1954). In B, a mouse hemidiaphragm was hung vertically in a vessel from which the fluid drained slowly while the liquid-air interface served as a recording electrode. The lower trace shows a small positivity in the endplate area, reflecting the slight hyperpolarization regularly observed in muscles with intact synaptic cholinesterase. After treatment of the same muscle with the irreversible anticholinesterase, paraoxon, there was a local depolarization (upward inflection) apparently due to non-quantal release of the $\mathrm{ACh}$ (upper trace). The reference electrode $(\mathrm{Ag} / \mathrm{AgCl}$ wire) was placed on the top of muscle (modified from Zemková et al. 1990). 
Later on, we used a similar procedure in several experiments (Zemková et al. 1990). Mouse hemidiaphragms which have a distinct endplate zone were hung vertically in a vessel from which the fluid drained slowly and the liquid-air interface served as a recording electrode. Extracellular records of the potential distribution along strips of the mouse diaphragm muscle also showed a depolarization in the presence of an antiAChE (Fig. 1B) which was maximal in the endplate zone.

\section{H-effect as electrophysiological estimation of the non-quantal release}

\section{Definition and conditions}

An important step to understanding the nature of NQR came when Katz and Miledi (1977) and Vyskočil and Illes (1977) provided direct electrophysiological evidence for it. The experimental approach was based on the assumption that if the acetylcholinesterase is inhibited, the ACh released can accumulate in the synaptic gap in quantities sufficient to cause significant postsynaptic membrane depolarization. Indeed, after inhibition of acetylcholinesterase (AChE), a small, slowly-growing depolarization of muscle fibers in the synaptic zone was recorded, which is eliminated by application of (+)-tubocurarine (TC) or $\alpha$-bungarotoxin $(\alpha \mathrm{BGT})$, well known blockers of postsynaptic nicotinic receptors. Hyperpolarization that develops after TC or $\alpha \mathrm{BGT}$ application through micropipette to the synaptic zone or into the bath was named the „H-effect“. Katz and Miledi (1977) demonstrated a small H-effect of some $0.04 \mathrm{mV}$ in the frog and we observed a much larger, approximately $2 \mathrm{mV} \mathrm{H}$-effect, in the the endplate area of mouse muscles treated with an anti-AChE (Vyskočil and Illes 1977). This hyperpolarization by TC was virtually absent in regions 3-5 $\mathrm{mm}$ distant from endplates, i.e. in the extrasynaptic zone of the diaphragm muscle of mice and rats.

In the standard protocol used for studying NQR of the ACh in most vertebrate muscles the nerve stumps were dissected from mice, rats or hamsters. In muscles with active cholinesterase, the average resting membrane potential (RMP) of fibers in the endplate zone is more negative by several $\mathrm{mV}$ (surplus hyperpolarization, see below and Fig. 1B) than in the endplate free region.

The muscle strips are then treated with the irreversible anti-AChE, e.g. diethoxy-p-nitrophenyl phosphate (armin), paraoxon or diisopropyl fluorophosphate for $30 \mathrm{~min}$ and then rinsed with normal
Liley or Ringer solutions. Measurements of RMP are performed 20-30 min afterwards in controls or in the presence of various drugs. The NQR of ACh causes depolarization of muscle fibres at the endplate zone as verified on occasion by the presence of MEPPs. It is quantified statistically by measuring membrane potentials with glass microelectrodes in 20 or more fibres during a 5-10 min period before, and in another 20 or more fibres 5-10 min after the addition of $10 \mu \mathrm{M}$ TC to the medium. As already mentioned, the differences (i.e. hyperpolarization, H-effect) between the mean RMPs under these two conditions are generally attributed to the non-quantal release of ACh. This method of rapid recordings of RMP from dozens of fibres before and after TC was accepted as the results are identical to those found by more laborious single fibre experiments (Katz and Miledi 1977, Vyskočil and Illes 1977, 1978, Yu and Van der Kloot 1990) that have been used to demonstrate the phenomenon (Fig. 2).
A

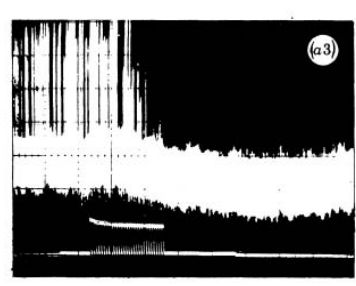

$B$

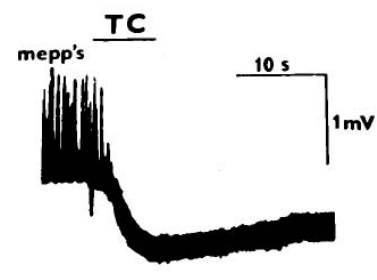

Fig. 2. The effects of (+)-tubocurarine (TC) on the membrane potential in the frog ( $A$, modified from Katz and Miledi 1977; time calibration $30 \mathrm{~s}$, amplitude calibration $84 \mathrm{nA}$ ) and mouse (B, modified from Vyskočil and Illés 1977) endplate with inhibited AChE. TC caused the MEPPs (rapid upward deflections, left part of the records) to disappear and endplate to hyperpolarize (slow downward deflection, the H-effect). The smaller H-effect in the frog endplate is apparently due not only to the lower input resistance of the frog muscle fibre membrane, but also due to the smaller non-quantal release when compared with mouse or rat.

It is necessary to note that the method of evaluating the magnitude of non-quantal ACh secretion by recording the size of the H-effect was not acknowledged immediately. Some authors (Grinnell et al. 1989, Meriney et al. 1989) argued that the H-effect may be only a laboratory phenomenon, which, possibly, is disclosed only in the presence of the AChE inhibitors having the weak cholinomimetic effects, whose elimination with TC leads to the hyperpolarization. Or the $\mathrm{H}$-effect can be a result of the ability of AChE inhibitors to stimulate liberation and accumulation of $\mathrm{ACh}$ exclusively in the isolated neuromuscular preparation. 
However, the several experiments counter these objections. Thus, we showed that the H-effect is recorded in the neuromuscular preparations, isolated from the animals, where blocking $\mathrm{AChE}$ in vivo produced an $\mathrm{H}$-effect, the magnitude of which was similar to that obtained under similar conditions in vitro (Nikolsky et al. 1992). The proposal that the H-effect is a consequence of the weak cholinomimetic effects of inhibitors of AChE was refuted by experiments, where after the non-quantal secretion was disrupted by different methods the addition of armin and paraoxon, the most widely used AChE inhibitors in non-quantal studies, did not produce a substantial cholinomimetic effect (Doležal et al. 1983, Vyskočil et al. 1983).

Convincing data that $\mathrm{H}$-effect is not the result of the direct action of anti-AChE treatment were obtained in experiments without AChE. First, in the joint culture of Xenopus motoneurons and myocytes the application of $\mathrm{TC}$ or $\alpha \mathrm{BGT}$ led to the significant hyperpolarization of the innervated muscle cell, what was not observed in the non-innervated myocyte (Sun and Poo 1985) (Fig. 3).
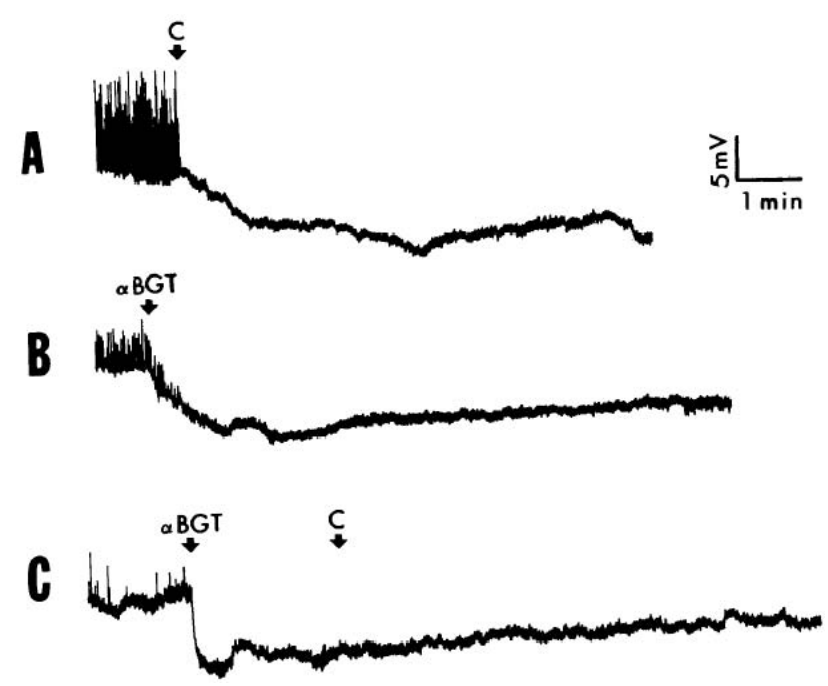

Fig. 3. A - hyperpolarization of muscle membrane potential induced by local application of $15 \mathrm{mM}(+)$-tubocurarine (C); $B$ - alike hyperpolarization induced by a-bungarotoxin (aBGT); C - local application of (+)-tubocurarine after the muscle membrane had been treated with a pulse of aBGT. (+)-tubocurarine did not induce further hyperpolarization of the membrane, suggesting that the hyperpolarization induced by $C$ and $\mathrm{aBGT}$ is probably due to the direct action of the drugs on the ACh receptors and disappearance of both MEPPs and NQR. Recordings from three different innervated muscle cells in 2-dayold Xenopus cultures (modified from Sun and Poo 1985).

In the muscles of 7-9 day mice, in which the $\mathrm{AChE}$ is still functionally insufficient, an H-effect was also recorded after the addition of $\mathrm{TC}$, again in the absence of any AChE inhibitors (Vyskočil and Vrbová 1993). Finally, an H-effect was observed during the application of TC to the endplates in the diaphragm muscles of adult mice, with collagen Q-deficient junctions (knockout mice). This collagen is critical for the anchoring of AChE in the basal lamina of synaptic gap and collagen Q-deficient junctions lack AChE completely (Minic et al. 2002).

Thus, there is strong evidence for considering the $\mathrm{H}$-effect as a valid electrophysiological response, which reflects non-quantal $\mathrm{ACh}$ release from the nerve ending. However, since the H-effect is based on the postsynaptic depolarization by NQR ACh, to understand it better it is necessary to follow the numbers, sensitivities and kinetics of the postsynaptic receptors as well as changes in the input resistances of the postsynaptic membrane.

\section{Ionic and temperature dependence}

To learn more about the factors controlling the proposed NQR, the effects of various modifications of the ionic contents of the bath on the H-effect have been investigated (Vyskočil et al. 1983).

Both the sizes of the evoked endplate potentials and the frequencies of the spontaneous MEPPs are influenced by the $\mathrm{Ca}^{2+}$ concentration in the bath, but with different time course. The H-effect is maximal in $2 \mathrm{mM}$ $\mathrm{Ca}^{2+}$, i.e. the concentration of the normal bath solution. Lowering the $\mathrm{Ca}^{2+}$ reduces the $\mathrm{H}$-effect with time and it is absent in preparations incubated in $\mathrm{Ca}^{2+}$-free solution for more than 60 min (Nikolsky et al. 1991b) (Fig. 4).

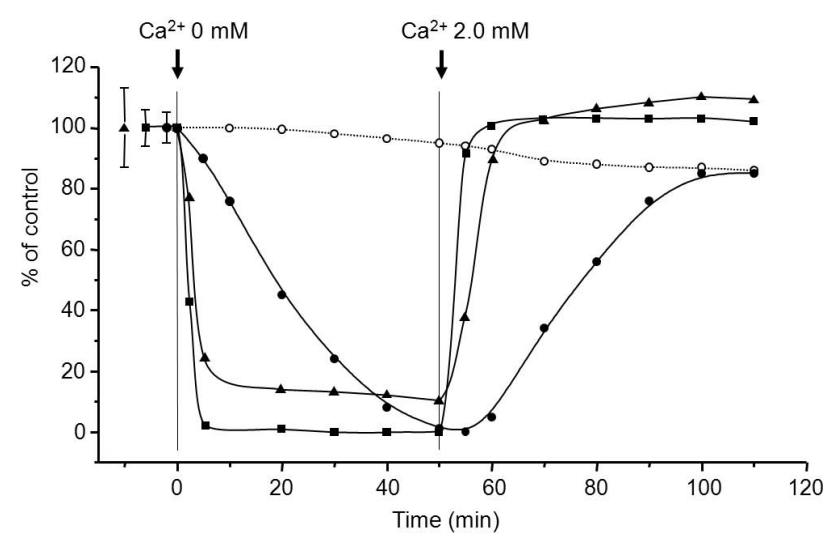

Fig. 4. The effect $\mathrm{Ca}^{2+}$ withdrawal and readmission on the endplate potential quantum content (squares), miniature end-plate potential frequency (triangles) and $\mathrm{H}$-effect (black circles). Open circles - spontaneous decline of the H-effect amplitude in $2.0 \mathrm{mM}$ $\mathrm{Ca}^{2+}$ and $10 \mu \mathrm{M}$ choline-containing solution. Abscissa - time in minutes; ordinate - changes in quantal and non-quantal ACh release expressed as percentage of the control values before $\mathrm{Ca}^{2+}$ omission. Every point represents mean from 4-7 experiments. The S.E.M. 's were usually less than $15 \%$ for most of the readings and are indicated only in the beginning of curves (modified from Nikolsky et al. 1991b). 
The H-effect also decreases as the $\mathrm{Ca}^{2+}$ level is increased above $5 \mathrm{mM}$ and it disappears in $15 \mathrm{mM} \mathrm{Ca}^{2+}$, while the frequency of MEPPs shows the expected dependence on the $\mathrm{Ca}^{2+}$ level in parallel recordings. A similar dependence on $\mathrm{Ca}^{2+}$ is present in embryonic neuromuscular synapses of Xenopus tissue in culture (Sun and Poo 1985) where the H-effect disappeared in $8 \mathrm{mM} \mathrm{Ca}^{2+}$. Most importantly, the time courses of the effects of $\mathrm{Ca}^{2+}$ concentration changes on quantal release (immediate) and H-effect (prolonged) are substantially different (Nikolsky et al. 1991b).

Increasing the $\mathrm{K}^{+}$concentration in the bath from 0.5 to $15 \mathrm{mM}$ and hypertonic treatment (both procedures increase MEPPs frequency) affects the H-effect only slightly in current clamp measurements but it is doubled under voltage clamp at a holding potential of $-70 \mathrm{mV}$ (Vyskočil et al. 1983).

A surprisingly strong dependency of the H-effect on the external level of $\mathrm{Mg}^{2+}$ has been found (Zemková and Vyskočil 1989, Vyskočil and Vrbová 1993). In the absence of $\mathrm{Mg}^{2+}$ the $\mathrm{H}$-effect is maximal; the presence of $1 \mathrm{mM} \mathrm{Mg}^{2+}$ reduces the $\mathrm{H}$-effect by one third and it is virtually absent at $3 \mathrm{mM} \mathrm{Mg}^{2+}$.

The temperature dependence of the process responsible for ACh release in the rodent diaphragm has a complex character. It has been established, that in the range from 10 up to $35{ }^{\circ} \mathrm{C}$ the size of $\mathrm{NQR}$ has two relative maxima at 20 and $35{ }^{\circ} \mathrm{C}$ and minima at 25 and $10{ }^{\circ} \mathrm{C}$, and in the latter case the H-effect is completely absent. At the same time, the amount of spontaneous quantal release is increased exponentially at rising temperatures (Lupa et al. 1986, Nikolsky and Voronin 1986). Thus, the two processes of ACh release possess different temperature and ion dependences indicating that NQR in particular may be governed by a rather complicated interplay of several independent mechanisms.

\section{Possible mechanisms of the non-quantal release}

\section{Vesicular ACh transporter}

Since the nerve terminal membrane should be virtually impermeable to a cation the size of $\mathrm{ACh}$, it is likely that there has to be some kind of transport system to move ACh across the terminal membrane. It has been proposed originally that the vesicular ACh transporters (VAChT) may play a role in non-quantal release of ACh (Edwards et al. 1985, Vyskočil 1985). Synaptic vesicles isolated from the electric organ of Torpedo have been shown to take up ACh by an active process (Parsons and Koenigsberger 1980). If the transport system underlying this uptake were present in the vesicles of the nerve terminal at the neuromuscular junction, and if the transport system retained its orientation following the incorporation of the vesicle membrane into the axon membrane during "kiss-and-stay" exocytosis, that is now the preferred mechanism at most synapses $(\mathrm{He}$ and $\mathrm{Wu}$ 2007), then it would move ACh from the axoplasm into the extracellular space and the synaptic cleft (Fig. 5).

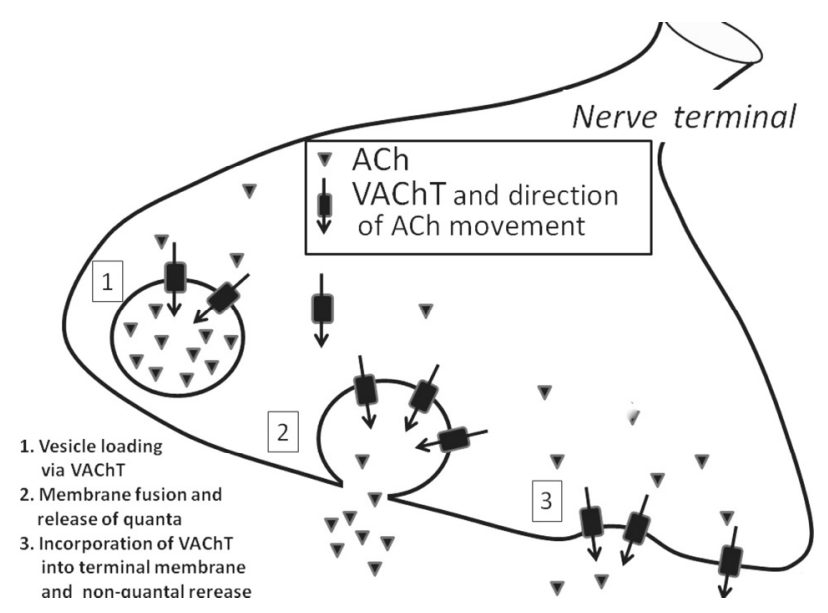

Fig. 5. Vesicular Ach-transporter scheme of the non-quantal Ach release.

To investigate whether this transport system is responsible for non-quantal release, the effects on the $\mathrm{H}$-response of agents which act on the transport of ACh into vesicles and of some other treatments and pharmacological agents have been examined. The most potent inhibitors of ACh transport in Torpedo synaptic vesicles among about 80 compounds investigated were vesamicol (phenylpiperidinocyclohexanol), quinacrine and tetraphenylborate (Anderson et al. 1983a,b). These compounds inhibit the H-effect and the concentrations estimated to produce $50 \%$ block of the hyperpolarization are quite similar to those producing the same level of block of ACh transport in Torpedo vesicles (Edwards et al. 1985).

In several muscle fibres in which the RMPs were measured over a period of time, the local application of vesamicol from a micropipette hyperpolarized the RMP within seconds without changes in the amplitude of the MEPPs (Vyskočil 1985). Therefore the reduction of the H-effect was of presynaptic origin and curare-like action of vesamicol was absent. 
The transport of ACh into the vesicles has been reported to be coupled with a proton concentration gradient, in which the vesicle interior is more acidic (Anderson et al. 1982). If the non-quantal release similarly requires a proton gradient, an increase in the bath $\mathrm{pH}$ at some level should inhibit the release by setting up a proton gradient in the direction opposite to that required for $\mathrm{H}^{+} / \mathrm{ACh}$ exchange. In buffers, at a bath $\mathrm{pH}$ 6.4 or 7.4 , the addition of TC produced the usual H-effect. However, at $\mathrm{pH} 8.4$ or 9.4 the addition of TC produced little or no H-effect as compared to the more acidic pHs (Edwards et al. 1985).

The potentiation of the H-effect by ouabain (Vyskočil and Illés 1977, Zemková et al. 1990) could be due to the fact that the block of $\mathrm{Na}^{+} / \mathrm{K}^{+}$- ATPase by the drug removes a source of protons within the nerve terminal; this would tend to make the cytoplasm more alkaline, and this change in the proton concentration gradient across the membrane might facilitate the AChproton exchange via the VAChT transport system. Another possibility is based on the finding that ouabain interferes with vesicle endocytosis and can thus prolong the time period during which the VAChTs are incorporated into the nerve membrane (Haimann et al. 1985). Thus, the effects of vesamicol, quinacrine, tetraphenylborate, $\mathrm{pH}$ changes, and in a less direct way also high frequency stimulation (Zemková et al. 1990) are consistent with the idea that NQR of ACh is produced by the presence of the ACh transport system in synaptic vesicles.

There are reports that embryonic myocytes are also capable of synthesizing and releasing ACh in both the quantal (Girod et al. 1995) and non-quantal manner (Fu et al. 1998). Vesamicol and quinacrine, vesicular transporter inhibitors, reduce the channel open probability caused by $\mathrm{ACh}$ released from myocytes in the presence of AChE-inhibitors neostigmine or physostigmine indicating that VAChT is also present in the myocyte membrane. In contrast in the adult endplate, intracellular alkalinization with $\mathrm{NH}_{4} \mathrm{Cl}$ inhibits the ACh release from myocytes, whereas extracellular alkalinization, brought about by replacing normal Ringer solution, with $\mathrm{pH} 8.6$ Ringer solution enhances ACh release (Fu et al. 1998).

\section{Choline transporter}

However, other experimentally based interpretations are also possible. Several experimental findings support the hypothesis that the mechanism of the non- quantal release of ACh can be realized by a high affinity choline transporter. One is the possible role of the choline transporter which in some vesicle populations can exchange $\mathrm{ACh}$ for choline (Nikolsky, personal communication). After choline is transported back into the nerve terminal from the synaptic cleft it becomes a precursor of ACh synthesis in the cytosol. The H-effect is completely blocked $10 \mathrm{~min}$ after the application of hemicholinium-3 which is a specific inhibitor of choline reuptake. Moreover, the $\mathrm{H}$-effect is also eliminated during the inhibition of the choline reuptake by the replacement of $\mathrm{Na}^{+}$in the bathing medium by $\mathrm{Li}^{+}$ (Nikolsky et al. 1991a). In addition, the presence of $1 \mu \mathrm{M}$ choline in the bath and $3 \mathrm{~Hz}$ nerve stimulation, which increase the rate of choline uptake prolong the H-effect after denervation for several hours (Nikolsky et al. 1991a) (Fig. 6).

There is still another possibility, that there is a population of synaptic vesicles in the membrane carrying both the VAChT and choline transporters, which have been found to be colocalized in the presynaptic terminals of cholinergic neurons in the ventral horn of the mouse spinal cord (Ferguson et al. 2003). This functional complex with choline transporter should underlie the NQR. The system could not transport $\mathrm{ACh}$ when the choline transporter is inhibited by hemicholinium-3 and vice versa, increased choline should facilitate not only the production of ACh required for $\mathrm{NQR}$, but also its release through VAChT. And finally one can speculate that the choline transporter, like the dopamine transporter (Carvelli et al. 2008) is a channel transporting choline retrogradely and ACh orthogradely. Yet, there is no evidence for or against this idea.

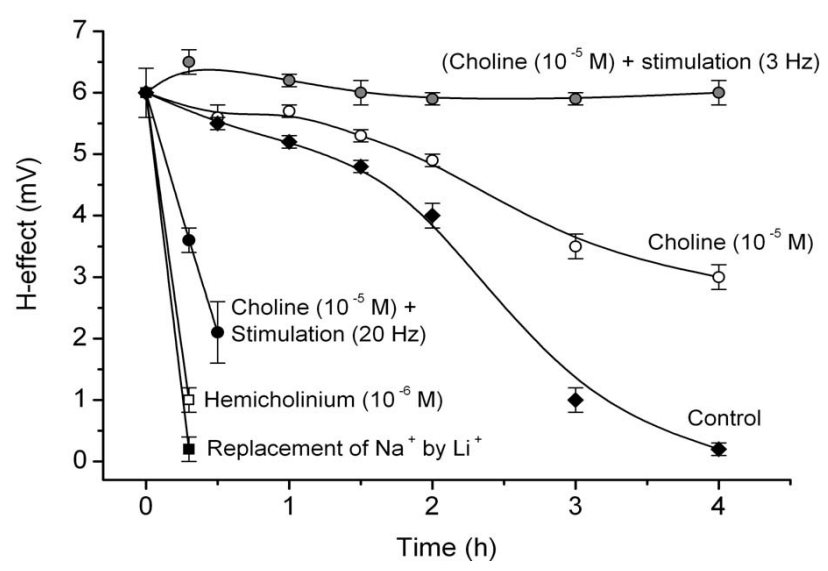

Fig. 6. The time course of the H-effect in different bath and stimulation paradigms (modified from Nikolsky et al. 1991a). 


\section{Size of non-quantal release}

Biochemical and bioassay methods show that spontaneous quantal secretion represents only a few percent of the total $\mathrm{ACh}$ released in vitro from the neuromuscular preparation into the bath (Mitchell and Silver 1963, Fletcher and Forrester 1975, Vizi and Vyskočil 1979). Comparison of the synaptic and extrasynaptic parts of the muscle have revealed that nearly half of the released $\mathrm{ACh}$ is of muscle origin (Mitchell and Silver 1963, Krnjevic and Straughan 1964, Potter 1970, Tuček 1982, Doležal and Tuček 1983, 1992). NQR has been demonstrated directly in myocytes (Fu et al. 1998). Thus, in mammals the level of nonquantal release of $\mathrm{ACh}$ is relatively large accounting for up to $90-98 \%$ of total ACh release at rest. About half of the NQR acetylcholine is released from motor nerve endings (Vizi and Vyskočil 1979).

In muscles in which the non-quantal release is blocked, for example, by reducing $\mathrm{Ca}^{2+}$ or raising $\mathrm{Mg}^{2+}$, an $\mathrm{H}$-effect of similar magnitude can be produced by application of approximately $0.1 \mu \mathrm{M} \mathrm{ACh}$; therefore we suppose that the level of $\mathrm{ACh}$ in the synaptic cleft in AChE-blocked diaphragms of the mouse or rat is of the order of hundreds of nanomols (Vyskočil et al. 1983). Interestingly, in frog muscles, where certain constraints about NQR, exist the magnitude of the much reduced H-effect produced by TC is matched by a much lower level of ACh (about 1-10 nM, Katz and Miledi 1977). However, other experiments have shown that also in frog the amplitude of the $\mathrm{H}$-effect can reach millivolts at extreme temperature $35^{\circ} \mathrm{C}$ (Vyskočil 1978).

The assumption that NQR produces a concentration in the synaptic cleft of tens of nanomoles is supported by other experimental data. We found that the RMP of the diaphragm muscle fibers with intact cholinesterase is more polarized by 1-3 $\mathrm{mV}$ in the synaptic area than in the extrasynaptic area (Vyskočil and Illés 1978, Vyskočil et al. 1983, 1995, Shih 1986, Nikolsky et al. 1994). This surplus polarization can be removed by the same factors that lead to the disappearance and $\mathrm{H}$-effect - denervation, raising $\mathrm{Mg}^{2+}$ or by reduction of $\mathrm{Ca}^{2+}$. At the same time, application of 10-100 nM ACh leads to reappearance of this surplus polarization (Vyskočil 1974, Vyskočil et al. 1983, 1995, Nikolsky et al. 1994).

The ACh release at frog neuromuscular junctions was studied by using outside-out patches of ACh receptor-rich membrane as a detector (Grinnell et al.
1989, Meriney et al. 1989). They did not detect - in contrast to the original findings of Katz and Miledi (1977) - any measurable NQR at the endplates after exposure to collagenase. This treatment might well destroy ACh transporters responsible for the NQR (Marastoni et al. 2008) as we observed a disappearance of the NQR (but not MEPPs) in mouse diaphragm after gentle collagenase treatment (Vyskočil, unpubIished observation). On the other hand, NQR from growth cones of embryonic neurones was found by direct biosensor measurement (Young and Poo 1983) (see also Fig. 3).

In mammals, the resting level of NQR of ACh from the nerve terminal is much larger than the quantal level (Vizi and Vyskočil 1979), while in frogs it is far less, at least at $20{ }^{\circ} \mathrm{C}$ (Katz and Miledi 1977, cf. Vyskočil 1978). In the first electrophysiological experiments on rodent preparations in physiological saline, H-effects of 1-2 $\mathrm{mV}$ were reported but in most subsequent papers values of about 5-6 mV (e.g. Mukhtarov et al. 1999, Galkin et al. 2001, Malomouzh et al. 2005, 2007) were found. Larger H-effects, up to 8-9 $\mathrm{mV}$, are found in rat diaphragms when nitric oxide (NO) synthase and guanylyl cyclase are inhibited (Mukhtarov et al. 2000, Malomouzh et al. 2003). ATP reduces the $\mathrm{H}$-effect dramatically, but does not eliminate it completely, unless a Rp-cAMP (an inhibitor of protein kinase) or a guanylyl cyclase inhibitor ODQ are also present. Therefore, one can speculate that extracellular ATP can regulate the major part of the H-effect and smaller parts in the range of 1-2 $\mathrm{mV}$ are dependent on another release route(s), as already mentioned above (VAChT or choline uptake system).

The role of ATP in controlling a substantial fraction of NQR is supported also by findings that both quantal and non-quantal spontaneous acetylcholine release increase during the first $30 \mathrm{~min}$ of hypoxia in a solution with normal extracellular calcium $\left(\left[\mathrm{Ca}^{2+}\right]_{\text {out }}=\right.$ $2.0 \mathrm{mM})$. Interestingly, in low calcium solutions $\left(\left[\mathrm{Ca}^{2+}\right]_{\text {out }}\right.$ $=0.4 \mathrm{mM}$ ), there is a significant increment of the nonquantal release while the hypoxia-induced ten fold increase of the MEPP frequency is virtually absent (Bukharaeva et al. 2005). This indicates that each of these two processes of release is influenced by different oxygen-sensitive mechanisms. The rise of MEPP frequency during the onset of hypoxia apparently requires $\mathrm{Ca}^{2+}$ entry into the nerve terminal, whereas the NQR can be increased by other factors such as the lower level of the ATP when its oxidative production is hindered. 


\section{Non-quantal release during denervation and reinervation}

After motor nerve section, the reduction in the total amount of ACh released, measured biochemically, precedes the loss of quantal release suggesting that spontaneous NQR decreases before quantal release (Tuček 1982). Biochemical estimates, however, cannot distinguish between the ACh of nerve terminal or muscle origin in innervated muscles. More direct measurements were therefore made of the progressive decline and recovery of spontaneous quantal ACh release and the $\mathrm{H}$-effect in the mouse diaphragm after intrathoracic nerve crush and during regeneration. One hour after nerve crush the H-effect had declined to $50 \%$ and four hours later, the H-effect disappeared completely (Nikolsky et al. 1996). There were no substantial changes in the MEPP frequencies and amplitudes during the first four hours of denervation. The MEPP frequencies then increased, but after six hours of denervation they decreased and after $16 \mathrm{~h}$ no MEPPs were found in any of the muscle fibers. The times of onset of these denervation changes in quantal release were only slightly dependent on the lengths of the intramuscular nerve branches as they were - similar in the proximal, central and distal parts of diaphragm (Nikolsky et al. 1996). This is in contrast to the results of similar experiments in the rat using the longer phrenic nerve where the onset times are dependent of the length of the nerve. The preferential disappearance of the NQR might be due to a very fast inhibition of ACh synthesis in the terminal leading to exhaustion of cytosolic ACh and thus of non-quantal release. A similar and even more rapid disappearance of the H-effect (within minutes) is observed after hemicholinium-3 or when $\mathrm{Li}^{+}$is substituted for $\mathrm{Na}^{+}$. Both these treatments inhibit the fast choline uptake into nerve terminal (Nikolsky et al. 1991a).

During reinervation, the $\mathrm{H}$-effect was detected in all muscle parts three days before quantal release, i.e. the reappearance of MEPPs (Nikolsky et al. 1996) (Fig. 7). The H-effect developed first on day 8 in the proximal endplates and then, with delays of 3 and 6 days in the central and distal areas. The first-appearing MEPPs following the NQR were often slow and were independent of $\mathrm{K}^{+}$, and great numbers of them were less than $0.2 \mathrm{mV}$ in amplitude. Full recovery of the MEPP frequency and $\mathrm{K}^{+}$and $\mathrm{Ca}^{2+}$ dependence were observed 20 days after the nerve crush in proximal parts and 30 days in distal parts of the diaphragm. It seems that

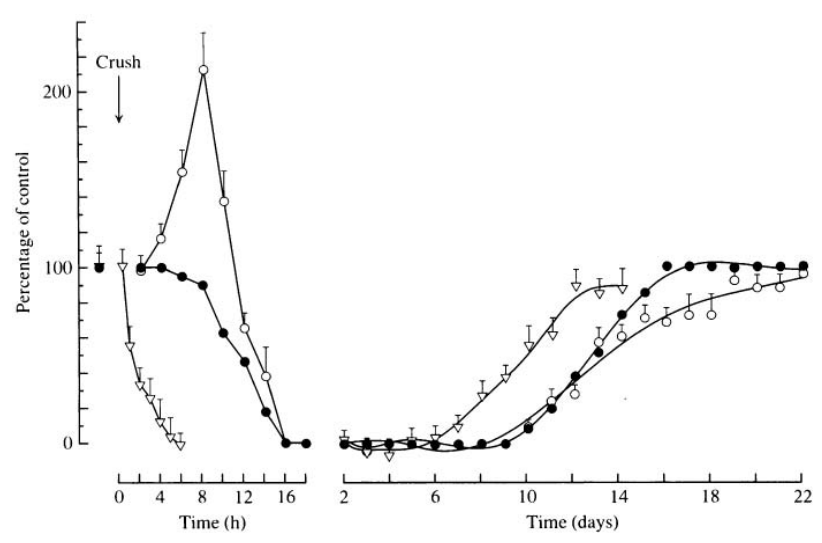

Fig. 7. Time courses of the frequencies of MEPPs (open circles), percentage of fibres with MEPPs (filled circles) and $\mathrm{H}$-effect (triangles) after nerve crush (arrow, time zero). Data were collected from the proximal part of the hemidiaphragm and are expressed as a percentage of the control values. Each point is the mean \pm S.E.M. from 10 muscles (3-15 fibres each) for MEPP frequency and mean \pm S.E.M. of $75 \mathrm{H}$-effect values from 3 muscles (modified from Nikolsky et al. 1996).

during axonal regrowth, the NQR precedes, or closely follows the morphological restoration of the neuromuscular contact. NQR can thus be considered as the first demonstration of ability of the nerve terminal to synthesize and release the transmitter during reinervation.

On the basis of reinervation data, NQR exists even without apparent quantal release. From the point of view of VAChT hypothesis, it might mean that either ACh-unloaded vesicles are fused ("invisible" MEPPs) or that quantal release and VAChT incorporation is not necessary for NQR as thought previously. Alternatively, during the early reinervation period, the VAChTs (or other yet unidentified transporter) might be synthesized and incorporated into the terminal membrane before they are embedded into the vesicles. Then they form an independent pathway for release of $\mathrm{ACh}$ from cytosolic pool which precedes vesicle maturation and quantal release.

\section{Regulation of the non-quantal release}

\section{Purinergic}

The role of ATP as a neurotransmitter or a co-transmitter is now generally accepted (for review Edwards and Gibb 1993, Ribeiro et al. 1996, Pankratov et al. 2006, Burnstock 2007). ATP is present in the synaptic vesicles at the neuromuscular junction in concentrations only several times smaller than those of the major transmitters, ACh in particular. Stimulation of the motor nerve releases it together with $\mathrm{ACh}$ in a $\mathrm{Ca}^{2+}$-dependent 
manner (Silinsky and Redman 1996). There are also other ATP release routes such as a constitutive ATP release from postsynaptic muscle fibers (Israël et al. 1976, Smith 1991, Cunha and Sebastiao 1993, Ribeiro et al. 1996, Santos et al. 2003). ATP and adenosine have been shown to affect evoked quantal release (Giniatullin and Sokolova 1998, Sokolova et al. 2003, Burnstock 2007). ATP but not adenosine, its degradation product, depresses the NQR, whereas both purines reduce the frequencies of MEPPs. This action was blocked by application of $\mathrm{P}_{2}$ receptor inhibitor suramin or of the protein kinase $\mathrm{C}$ inhibitor staurosporine (Galkin et al. 2001). This supports the idea that there are different pathways for regulation of both types of release.

The sensitivity of the H-effect to the action of ATP is quite high. In relatively low concentrations $(10 \mu \mathrm{M})$ ATP decreased the magnitude of the H-effect from $5 \mathrm{mV}$ to $1.5 \mathrm{mV}$ (by about $70 \%$ ). Thus ATP might initiate an effective feedback mechanism modulating $\mathrm{ACh}$ release. The comparison of purines also allows the reconsideration of the VAChT hypothesis. As already stated, NQR might proceed through the vesicular ACh transporters which are introduced into the presynaptic membrane during the fusion process underlying quantal transmitter release. The finding that ATP depressed not only non-quantal, but also quantal release might suggest the reduction in the number of incorporated VAChTs. However, the absence of adenosine action on non-quantal release, together with its approximately $50 \%$ depression of the miniature endplate current (MEPC) frequency, decreases the likelihood that the $70 \%$ fraction of NQR inhibited by ATP is determined simply by the number of vesicle transporters incorporated into the terminal membrane during vesicle fusion. On the other hand, the small part of the 1-2 mV H-effect, found to be insensitive to ATP but sensitive to the VAChT inhibitor vesamicol which eliminates $\mathrm{H}$-effect completely (Edwards et al. 1985) might be regulated by transporters or fusion proteins in the terminal membrane.

What intracellular metabolic route might be involved in the NQR inhibition mediated by ATP? Metabotropic $\mathrm{P}_{2 \mathrm{Y}}$ receptors might be coupled to multiple intracellular cascades such as phospholipase $\mathrm{C}$, and phospholipase $\mathrm{A}_{2}$ and cAMP or guanylyl cyclase. First, we analyzed the role of guanylyl cyclase since its cascade has recently been shown to participate in the modulation of non-quantal release in rats (Mukhtarov et al. 2000, Malomouzh et al. 2003). However, the inhibition of guanylyl cyclase by the specific inhibitor ODQ did not change the depressant action of ATP on NQR. It seems obvious that guanylyl cyclase and purinergic modulators are acting through distinct pathways (Galkin et al. 2001, but cf. Ohtani et al. 2000).

It is known that ATP is able to suppress the production of cAMP and to lower the subsequent activation of protein kinase A. On the other hand, in neuroblastoma cells ATP can stimulate the intracellular production of cAMP (Matsuoka et al. 1995). Pretreatment of the neuromuscular preparation by a cAMP analogue, Rp-cAMP, an inhibitor of protein kinase A, failed to influence the action of ATP and thus the protein kinase A route is apparently not involved. In other cells ATP activates phospholipase $\mathrm{C}$ and production of $\mathrm{IP}_{3}$ and DAG with subsequent activation of protein kinase C (for review Burnstock 2007). This is a more likely possibility as pretreatment by the protein kinase $\mathrm{C}$ inhibitor staurosporine completely prevented the depressant action of ATP on the non-quantal ACh release.

The intriguing question, however, is whether the non-quantal release of $\mathrm{ACh}$ is also accompanied by release of ATP in parallel, as with the co-release of these two in a quantal manner. The expression of stretchactivated gadolinium sensitive channels in the presynaptic membrane which might help intracellular ATP to cross the cell membrane seems to support such a suggestion. During muscle contraction, ATP and its metabolites are released from skeletal muscle in gadolinium-sensitive manner, thus raising the interstitial concentration. Once release, it might lead not only to activation of $\mathrm{P}_{2 \mathrm{X}}$ receptors on muscle-fiber afferents and reflexively increase of arterial blood pressure and heart rate (Li et al. 2003, 2008) but it can act as a modulator of NQR. Our finding that a $\mathrm{P}_{2}$ antagonist increased the level of non-quantal ACh release favors such a tonic action of endogenous ATP. Therefore the possibility exists that there is feedback inhibition of transmitter release via accumulation of endogenous ATP initially directed towards the non-quantal and quantal release and which is augmented later by the appearance of adenosine during enzymatic degradation of ATP and the combined action of these purines. In view of this modulatory role of both purines on quantal release it is worthwhile to note the additivity in the actions of ATP and adenosine. $\mathrm{Mg}^{2+}$, which is a co-factor for ATP-dependent processes, is also known to depress non-quantal release in the range of 3-4 mM. Last, but not least, variations in ATP levels in the synaptic cleft during direct or indirect stimulation 
might also explain the observations about rapid changes in the magnitude of the NQR and the earlier discrepancies between the electrophysiological and biochemical data on transmitter release under the action of different modulators.

\section{Glutamatergic}

To date, there is much evidence in favor of idea that, in the vertebrate neuromuscular synapse glutamate (Glu) could serve as modulator of the synaptic transmission. Glu is present in the cytoplasm of motoneurons (Meister et al. 1993), is associated with synaptic vesicles (Waerhaug and Ottersen 1993) and is released as a co-transmitter with $\mathrm{ACh}$ into the synaptic cleft (Vyas and Bradford 1987, Nishimaru et al. 2005). Glutamate transporters and NMDA receptors have been identified in the endplate (Berger et al. 1995, Grozdanovic and Gossrau 1998, Lück et al. 2000). Glu can modulate the quantal release of ACh in frogs (Pinard et al. 2003) whereas in mammals with massive NQR, the quantal release is apparently not affected (Malomouzh et al. 2003). On the other hand, we have found a strong inhibitory effect of glutamate on NQR of ACh (Malomouzh et al. 2003). It seems that glutamatergic modulation of NQR is selective for this type of release. This is unlike purinergic modulation, where there is suppression of both quantal and non-quantal ACh release by ATP.

We found that the depressant effect of Glu on NQR is mediated by activation of NMDA receptors and the entry of $\mathrm{Ca}^{2+}$ due to a subsequent increase in the activity of a $\mathrm{Ca}^{2+}$-dependent $\mathrm{NO}$-synthase. $\mathrm{NO}$ is formed in the muscle fibers, which then diffuses through the synaptic cleft and acts retrogradely at the motor nerve terminals, where it activates NO-sensitive guanylyl cyclase. This leads, ultimately, to a reduction of the NQR (Malomouzh et al. 2003).

Glutamate can be released not only from the motor nerves, but it can also be formed in the synaptic gap from the neuropeptide $\mathrm{N}$-acetylaspartylglutamate (NAAG), which is the most common neuropeptide in nervous tissue (Neale et al. 2000). NAAG attracts attention because there are some indications that this dipeptide functions as a neurotransmitter in certain central synapses, particularly in the optic tract (Tsai et al. 1988, Moffett et al. 1990, Molinar-Rode and Pasik 1992, Neale et al. 2000). NAAG may be involved in neurotransmission in two ways: directly as an agonist on different glutamate receptors (Westbrook et al. 1986,
Sekiguchi et al. 1992, Valivullah et al. 1994, Wroblewska et al. 1997, Neale et al. 2000, Sanabria et al. 2004) and also as a precursor of the glutamate that is produced by hydrolysis by the enzyme glutamate carboxypeptidase II (GCP II, called also NAALADase) in extracellular space (Blakely et al. 1988, Cassidy and Neale 1993). This peptidase is a membrane-bound protein present in perisynaptic Schwann cells surrounding the rat neuromuscular synapse (Berger et al. 1995). We found that NAAG also significantly decreases the H-effect, similarly to ATP and glutamate, but only the isomer which can be hydrolyzed and produce glutamate is active. The other product of the hydrolysis, $\mathrm{N}$-acetylaspartate is without effect on the H-effect. The activity of GCP II in the endplate was documented by the absence of glutamate during selective inhibition of the enzyme as determined by direct radioenzymatic measurement of the labeled Glu released from the NAAG. These results point to the possible role of glutamate and its precursor in the regulation of the NQR in vivo (Malomouzh et al. 2005) but direct electrophysiological demonstration of the Glu action on cholinergic synapse is, up to now, restricted only to H-effect and early postdenervation depolarization (Urazaev et al. 1998, Vyskočil 2003).

\section{Cholinergic}

The autoregulation of the quantal secretion of $\mathrm{ACh}$ at the neuromuscular synapse has been studied by many authors who demonstrated the role of nicotinic and muscarinic autoreceptor subtypes (Ciani and Edwards 1963, Wessler et al. 1988, Shakiryanova et al. 1994, Fu and Liu 1997, Slutsky et al. 1999, 2001, Oliveira et al. 2002, Santafé et al. 2003, 2006, Van der Kloot 2003, Nikolsky et al. 2004, Timóteo et al. 2008). Whereas the nicotinic regulation is hard to demonstrate because standard cholinolytic drugs such as curare prevent the estimation of the H-effect, we demonstrated the importance of muscarinic regulation for the NQR.

Muscarine and oxotremorine, both classical muscarinic agonists, were found to reduce the H-effect. The depressing effect of oxotremorine reaches a maximum in nanomolar concentrations and is eliminated by the specific M1 antagonist pirenzepine (Malomouzh et al. 2007). It turns out that the reduction of NQR does not proceed in the absence of extracellular $\mathrm{Ca}^{2+}$ similar to glutamate which is also inactive in the absence of $\mathrm{Ca}^{2+}$. This pointed to the possibility that there is a calciumdependent synthesis of NO which depresses the NQR. Further data support this idea included the finding that the 
inhibitory effect of oxotremorine is completely absent in the presence of NO-cascade inhibitors, namely L-NAME (non-selective NO-synthase inhibitor), hemoglobin (scavenger of extracellular NO molecules), ODQ (inhibitor NO-sensitive guanylyl cyclase) and the calmodulin antagonist calmidazolium (Malomouzh et al. 2007). Calmodulin is apparently necessary for $\mathrm{Ca}^{2+}$ dependent activation of the NO synthase (Spratt et al. 2007). There is an effective negative feedback system for the control of NQR of $\mathrm{ACh}$ : the more $\mathrm{ACh}$ is released from the nerve terminal, the more NO is produced in the muscle, which then diffuses to the nerve terminal and decreases the intensity of ACh NQR via activation of guanylyl cyclase and production of cGMP.

Interestingly, an increase of intracellular cGMP concentration significantly accelerates vesicle endocytosis (Petrov et al. 2008) and this might, according to the VAChT hypothesis, reduce the NQR by retraction of VAChT from the nerve terminal membrane. Pharmacological inhibition of soluble guanylyl cyclase, on the other hand, slows down the rate of recycling as well as endocytosis of synaptic vesicles (Petrov et al. 2008) and in parallel, as we have shown with regard to the H-effect, that NQR increases (Mukhtarov et al. 2000, Malomouzh et al. 2003, 2007). These results suggest that the cGMP-dependent pathway controls both the vesicular cycle and NQR.

Thus, the NQR at the mammalian neuromuscular junction can be regulated from several sites of the synapse: 1) Presynaptically by purines (ATP) released independently or during quantal transmission and 2) presynaptically and postsynaptically by the $\mathrm{Ca}^{2+}-\mathrm{NO}$ cascade via muscarinic and glutamate receptors.

\section{Physiological implications}

\section{Surplus polarization of muscle fibres at the endplate zone}

The resting membrane potential at the diaphragm, controlled mainly by the voltage dependent $\mathrm{K}^{+}$channel (delayed rectifier, Edwards and Vyskočil 1984), has been observed to be significantly more negative (by 2-4 mV) in the endplate zone than in the endplate-free area. In particular, in the mouse diaphragm with intact cholinesterase the mean value of the RMP is about $-85 \mathrm{mV}$ in the junctional area and about $-82 \mathrm{mV}$ in the extrajunctional zone at $22{ }^{\circ} \mathrm{C}$. The surplus hyperpolarization of the endplate, therefore, is $3 \mathrm{mV}$. It is somewhat higher at $37{ }^{\circ} \mathrm{C}$, about $4 \mathrm{mV}$ (Thesleff et al. 1974, Vyskočil and Illés 1978, Vyskočil et al. 1983)
(Fig. 1B). However its origin remained obscure until it was found that the hyperpolarization is caused by an ACh-potentiated (Dlouhá et al. 1979) electrogenic $\mathrm{Na}^{+} / \mathrm{K}^{+}$-pump (Caldwell and Betz 1984) operating during the action of NQR (Nikolsky et al. 1994). The addition of $1 \mu \mathrm{M}$ ouabain, an inhibitor of $\mathrm{Na}^{+} / \mathrm{K}^{+}$-pump, abolished this hyperpolarization of the endplate zone in less than $5 \mathrm{~min}$.

Within $4 \mathrm{~h}$ of nerve section NQR is decreased (in the rat) or is absent (in the mouse) (Nikolsky et al. 1991a, 1996, Zemková et al. 1990). At that time, quantal release is still maintained and the MEPPs frequency and other parameters are unchanged. In muscles excised $4 \mathrm{~h}$ after denervation, the hyperpolarization at the endplate zone has disappeared completely. In muscles excised 4-5 $\mathrm{h}$ after denervation, the addition of $50 \mathrm{nM}$ ACh (an amount simulating the NQR of ACh) causes a hyperpolarization of the endplate zone of about 3-4 mV, whereas there was no change in the resting membrane potential of the extrajunctional zone either before or 10 min after application of ACh (Nikolsky et al. 1994). It follows from these data that the surplus hyperpolarization of muscle fibers is most probably caused by the NQR of acetylcholine from the nerve terminal.

An interpretation such as this obviously raises several questions. In particular, how can the NQR ACh escape hydrolysis by intrasynaptically located AChE and reach the subsynaptic membrane? One possibility is that the acetylcholine leaves the terminal at sites where AChE is less concentrated or even absent. However, clear evidence about non-homogeneity of $\mathrm{AChE}$ along the cleft has yet to be found.

Another possible reason for the escape from hydrolysis of most of the NQR released ACh might be that the AChE is not sufficiently activated by the low ACh concentration despite its continual release. This idea seems to be in accord with the experiments of Augustinsson (1948), who showed that the rate of hydrolysis of ACh by AChE decreases sharply when the concentration of $\mathrm{ACh}$ is less than $100 \mu \mathrm{M}$ (cf. also Ecobichon and Israel 1967). Each catalytic subunit of AChE has two allosterically regulated ACh binding sites which have to be occupied simultaneously for full activation, and this occurs only when ACh is present at high concentrations (Taylor 1991). Moreover, the enzyme is fixed at the basal lamina and this provides an opportunity for a number of free ACh molecules to bypass the enzyme and reach the subsynaptic membrane.

As far as the mechanism by which ACh induces 
hyperpolarization in muscles with intact $\mathrm{AChE}$, the insensitivity of this phenomenon to TC almost excludes a direct role for postsynaptic nicotinic receptors. On the other hand, a $\mathrm{Na}^{+} / \mathrm{K}^{+}$-ATPase is likely to be involved in the hyperpolarization since it is blocked by ouabain within several minutes. Evidently, the 2-3 $\mathrm{mV}$ hyperpolarization is not due to higher internal electrogenic efficacy (Martin and Levinson 1985) of the $\mathrm{Na}^{+} / \mathrm{K}^{+}$-pump in the endplate zone as we found no differences in the maximal electrogenic effect between the endplate and endplate-free zones in $\mathrm{Na}^{+}$-loaded muscles (Vyskočil et al. 1987a,b).

This excludes the possibility that the pump located at the endplate is more active per se than that located extrasynaptically (Nikolsky et al. 1994). On the other hand, the activity can be enhanced by ACh (Pinsker and Kandel 1969). Previous studies have shown that 0.5 to $1 \mu \mathrm{M}$ ACh does not activate the electrogenic pump when silent (without external $\mathrm{K}^{+}$), but facilitates it when the muscle fibers are loaded with $\mathrm{Na}^{+}$and the pump activity is high (Dlouhá et al. 1979, 1980, Vyskočil 1979, Vyskočil et al. 1987a). The transporting pump protein at the endplate zone might therefore have a site modulated by ACh (Dlouhá et al. 1979, Elfman et al. 1982). Interestingly, colocalization of both proteins has been demonstrated (Doia and Iwasakib 2008). The $\mathrm{Na}^{+} / \mathrm{K}^{+}$ATPase accumulates at postsynaptic sites and appears to surround ACh receptors to maintain rigid clusters at the C. elegans neuromuscular junction.

In addition to the direct potentiation by $\mathrm{ACh}$, the electrogenic activity of the pump might be promoted by a higher resting $\mathrm{Na}^{+}$influx at the endplate. Sodium channels are concentrated deep in the neuromuscular junction folds, as has been shown electrophysiologically (Thesleff et al. 1974, Betz et al. 1984, Beam et al. 1985, Lupa et al. 1993) and immunocytochemically (Haimovich et al. 1987, Lupa et al. 1993, for review Slater 2008). Their spontaneous opening that was suggested already by Edwards (1982) might lead to a local increase of the internal $\mathrm{Na}^{+}$concentration (Betz et al. 1984, Jackson 1994). In the presence of NQR ACh, this $\mathrm{Na}^{+}$is removed from the cell and this pumping permanently hyperpolarizes the subsynaptic membrane and creates local ouabain-sensitive currents (Caldwell and Betz 1984).

\section{Early postdenervation depolarization}

The first change after nerve section is a depolarization of the muscle fibre RMP which affects excitability and contraction. It has been shown that denervated muscle fibres of the rat diaphragm with the short nerve stump kept in a tissue culture medium are depolarized by about $8-10 \mathrm{mV}$ (10-12\% of the control RMP) within 3-4 h after denervation (Bray et al. 1976, 1982, Urazaev et al. 1995, 1997, 1998, 1999, 2000). An inward-directed, furosemide-sensitive chloride transport starts to operate at that time and is believed to be the main cause not only for this early depolarization but also of the other postdenervation alterations such as the loss of ability of the muscle fibres to control its volume in hypertonic solutions (Urazaev et al. 1999), the presence of anode break excitation (Ashihara and Marshall and Ward 1974, Švandová et al. 2001, Trayanova 2005) and most probably for the voltage-dependent appearance of the extrasynaptic ACh receptors (Švandová et al. unpublished, cf. Huang et al. 1993). NQR - similarly to surplus polarization - disappears at exactly the same time when early postdenervation depolarization (EPD) develops, i.e. 3-4 $\mathrm{h}$ after nerve section. However, in the presence of $50 \mathrm{nM}$ carbacholine or $50 \mathrm{nM} \mathrm{ACh}$ in the bath (concentrations to mimic the effect of the NQR of $\mathrm{ACh}$ ), the EPD is substantially reduced, by $80 \%$ (Urazaev et al. 1997, 1999, 2000). The NQR is therefore the main "trophic" impulse stimulating the $\mathrm{Ca}^{2+}$ influx, NO production and NO cascade-mediated phosphorylation which maintain the $\mathrm{Cl}^{-}$inward current at a low level and RMP at a high level. After nerve section, this protection of NQR disappears and the now probably dephosphorylated transporter moves $\mathrm{Cl}^{-}$inside, the $\mathrm{Cl}^{-}$ equilibrium potential becomes more positive and the muscle membrane becomes depolarized.

Nitric oxide synthase inhibition therefore imitates at least partially the postdenervation changes even in fully innervated rat muscles. An intriguing idea (Vyskočil 2003) would be that the direct stimulation of denervated muscles (even by subthreshold pulses), which is known to partly overcome the effects of the absence of nerves (Brenner 1988), increases the intracellular $\mathrm{Ca}^{2+}$ due to release from the endoplasmic cisternae or by promoting the $\mathrm{Ca}^{2+}$ inward fluxes during depolarization, which restores the NO-cascade and thus mimics the action of NQR from motor nerve endings.

\section{Interspecies comparisons}

In muscles isolated from golden hamsters, the frequency of the spontaneous exocytotic release of quanta measured as MEPPs, is lower than in mouse or rat, particularly in muscles from hibernating hamsters 
(Moravec and Vyskočil 2005). If NQR depends on the quantal release, then the H-effect should differ in endplates from rat and awake and hibernating hamsters. We therefore compared the onset of EPD and levels of the H-effect with the frequencies of MEPPs in rat, and in awake and hibernating golden hamsters. The H-effect was substantially smaller in awake hamsters than in rats and was very small in hibernating hamsters and the smaller the non-quantal release, the faster was the development of the early postdenervation depolarization.

The half-decay time $\left(\mathrm{T}_{1 / 2}\right)$ of the development of the early postdenervation depolarization in muscle fibres of the mouse was $120 \mathrm{~min}$ : it was shorter in muscles from active hamsters $\left(\mathrm{T}_{1 / 2}=60 \mathrm{~min}\right)$ and even shorter in those from hibernating hamsters $\left(\mathrm{T}_{1 / 2}=25 \mathrm{~min}\right)$. This reciprocal correlation between the sizes of the H-effects and the rates of early depolarization indicates once more that non-quantal release is important for maintaining the RMP.

Under the low level of metabolism during hibernation, the actual level of ATP in the endplate vicinity might be the crucial regulatory factor for transmitter release. As already stated, the NQR is very sensitive to the action of ATP (Galkin et al. 2001). It has been reported that an enhancement of ATP release from the sympathetic perivascular nerves may occur in muscles from hibernating hamsters, probably as a result of coldinduced depolarization (Saito et al. 2001). One intriguing possibility therefore is that the low level of spontaneous release of transmitter, both quantal and non-quantal, is caused by higher purinergic tonus in the muscles during hibernation.

The finding that the smaller H-effect in awake hamster as compared with the mouse, is accompanied by a reduction in the frequency of MEPPs and that a negligible $\mathrm{H}$-effect was detected in hibernating hamsters where the MEPP frequency was only $5 \%$ of the frequency in mouse suggests that the reduction in the number of incorporated VAChTs, may be responsible for NQR.

\section{Desensitization and non-quantal release}

The treatment of endplates with an anti-AChE prolongs the decay phase of a single quantal response (MEPP or MEPC). This postsynaptic potentiation is a consequence of the repetitive binding and activation of postsynaptic receptors during the dispersion and diffusion of the non-hydrolyzed ACh out of the cleft (Hartzell et al. 1975, Feltz and Trautmann 1980, Giniatullin et al. 1989).
The extent of this prolongation is the same irrespective of the presence of NQR.

When NQR is potentiated by zero $\mathrm{Mg}^{2+}$, the decays of MEPCs become increasingly faster over several hours (Giniatullin et al. 1993). Increase of temperature from 15 to $26^{\circ} \mathrm{C}$ and the presence of the desensitizationpromoting drug proadifen accelerate the rate of shortening of the MEPCs. In contrast, this shortening of the MEPCs time course does not occur in the absence of $\mathrm{NQR}$, for example in solutions with elevated $\mathrm{Mg}^{2+}$ or several hours after denervation. These observations are consistent with an increase in receptor desensitization due to NQR. It is obvious that the repetitive binding and the resulting prolongation of decay would be greater if both the concentration of $\mathrm{ACh}$ and receptor density were high. Conversely, repetitive binding and therefore decay time would be reduced if either the ACh concentration or the receptor density decreased, as happens in the presence of ACh receptor inhibitors or during desensitization.

Desensitization could shorten the quantal responses in two ways: i) by decreasing the density (number) of functioning receptors or ii) by decreasing the amount of $\mathrm{ACh}$ available for repetitive binding by "trapping" a portion of ACh molecules on inactive desensitized receptors. This "trapping" could be quite significant since the affinity of desensitized receptors for $\mathrm{ACh}$ is increased by two orders of magnitude. Immediately after release, the quantal ACh activates the available receptors facing the active zone so that the MEPC amplitude is maximal. Amplitude remains almost maximal even if only small fractions (say $5 \%$ ) of the receptors are already desensitized. As a result of this initial activation, a further proportion of the receptors become desensitized, the numbers of receptors available for repetitive binding is decreased and the decay time is reduced. These desensitized receptors could continue to trap ACh molecules, thereby reducing even further the probability of repetitive binding. This number definitely depends on the extent of NQR. NQR could also "saturate" desensitized receptors and thus allow for quantally released $\mathrm{ACh}$ molecules to bind preferentially and repetitively to non-desensitized receptors.

\section{Non-quantal release and polyneuronal innervation}

Endplates of skeletal muscle fibres of newborn rats are contacted by several axons (Redfern 1970). In rat muscles this polyneuronal innervation gradually decreases during the first few weeks after birth, until the adult state is achieved where individual endplates are 
contacted by a single axon (Brown et al. 1976, O'Brien et al. 1978). Neuromuscular activity plays an important role in the process of elimination of excess contacts. A reduction of neuromuscular activity produced by tetrodotoxin (Thompson et al. 1979) or by surgical procedures such as tenotomy (Benoit and Changeux 1975) or spinal cord section (Zelená et al. 1962) prolongs the time of elimination, while increased neuromuscular activity induced by electrical stimulation of the motor nerve, or by muscle overload, increases the rate at which nerve-muscle contacts are eliminated (Zelená et al. 1962, O'Brien et al. 1978). In these experiments activity was altered in both the pre- and postsynaptic parts of the neuromuscular system. Experiments to elucidate the involvement of the postsynaptic part of the endplate in the process of synapse elimination revealed that the activation of the ACh receptor and the consequences of this activation play an important role. Blocking the response of the neuromuscular junction of the rat soleus muscle by treatment with $\alpha$-bungarotoxin during the later stages of synapse elimination reduced the loss of neuromuscular contacts (Duxson 1982, Greensmith and Vrbová 1991), while increasing the response of the postsynaptic membrane by treatment with anti-AChE enhances the rate at which nerve-muscle contacts are lost (O'Brien et al. 1980, 1984, Duxson and Vrbová 1985). In vitro experiments showed that even within a span of $2 \mathrm{~h}$ a large number of neuromuscular contacts are lost if the muscle is exposed to $\mathrm{ACh}$ or its motor nerve stimulated in the presence of an AChE blocker (O'Brien et al. 1980). These results taken together indicate that the activation of the acetylcholine receptor plays an important role in the process of synapse elimination. Such an activation of ACh receptors can be brought about under physiological conditions by released quanta or more importantly by NQR. The contribution of the NQR to the process of elimination of polyneuronal innervation could be important, because of the prolonged duration of this event, which can cause a long-lasting depolarization of the postsynaptic membrane (Zemková et al. 1990). This depolarization is probably greater in young developing muscle fibres when the activity of $\mathrm{AChE}$ at the neuromuscular junction is relatively low (Zelená 1962). The substantial participation of this non-quantal $\mathrm{ACh}$ release in the remodeling of entire neuromuscular junction during postnatal development is present in diaphragms from rat pups aged 8-9 days. H-effect at these young endplates is larger, even more pronounced than in adults. Unlike in adults, the $\mathrm{H}$-effect of about $2 \mathrm{mV}$ can be demonstrated even when the muscles are not treated with an anti-AChE. In the presence of an anticholinesterase the H-effect is greater and it is further enhanced by low $\mathrm{Mg}^{2+}(0.1 \mathrm{mM})$ and reduced by high (4 mM) concentrations. Thus the regulation of the NQR at neuromuscular junctions of developing rat muscles is similar to that seen in adult mammalian muscles.

Preincubating the muscles from rat pups in solutions where NQR is increased by lowering $\mathrm{Mg}^{2+}$ causes a significant reduction of neuromuscular contacts estimated by the endplate potentials produced by graded nerve stimulation and endplate potential records. This reduction does not occur when muscles are incubated in high $\mathrm{Mg}^{2+}$, when $\mathrm{NQR}$ is reduced. Increasing quantal release by high $\mathrm{Ca}^{2+}$ also reduces the neuromuscular contacts. Within $3 \mathrm{~h}$ most muscle fibres have only a single nerve input. Also histological examination of soleus muscle fibres treated with an anti-AChE showed that muscles incubated in solutions with low $(0.1 \mathrm{mM})$ concentrations of $\mathrm{Mg}^{2+}$ had significantly fewer neuromuscular contacts than those incubated in high concentrations of $\mathrm{Mg}^{2+}$.

The likely explanation of the effect of treatment with anti-AChE is that it allows the ACh to act for longer periods of time to depolarize the muscle fibre. Apparently NQR of ACh plays an important role in the elimination of polyneuronal innervation also during normal development. The long duration of the NQR compared to the short lasting MEPP would cause a much longer lasting depolarization of the muscle membrane. It has been proposed (Vyskočil and Vrbová 1993) that $\mathrm{K}^{+}$ released from muscle fibres during NQR ACh-evoked depolarization may cause $\mathrm{Ca}^{2+}$ to enter presynaptic terminals. In smaller terminals the $\mathrm{Ca}^{2+}$ might reach high enough concentrations to allow the $\mathrm{Ca}^{2+}$ activated neutral proteases (calpaines) to dismantle neurofilaments in the nerve endings and start the withdrawal of surplus nerve terminals (O'Brien et al. 1980, 1984, Connold et al. 1986, Zhu and Vrbová 1992, Ijkema-Paassen and Gramsbergen 2005). Interestingly, at least 30 percent of sartorius muscle fibres of adult frogs (having negligible NQR, Katz and Miledi 1977) are innervated by two or more axons at a single end-plate zone (Vyskočil and Magazanik 1977).

\section{Concluding remarks}

The non-quantal release of transmitter is an important factor during synaptogenesis as well as in adult 
endplates; it affects polyneural innervation of developing muscles, supports higher excitability of the endplate subsynaptic membrane by surplus polarization and protects the RMP from postnenervation depolarization. NQR might shorten the endplate potentials by promoting postsynaptic receptor desensitization when AChE is inhibited during anti-AChE poisoning (Kovyazina et al. 2003, Vyskočil 2006), and thus overcome at least partly the congestion of the synapse by non-hydrolyzed ACh. It has also been demonstrated that the depolarization of postsynaptic muscle fiber membrane by NQR develops in vivo after anti-AChE injection and it might therefore be one of the important factors determining synaptic failure and morphological changes on both pre- and postsynaptic parts of the endplate seen during anti-AChE poisoning.

Apparently NQR is not restricted to the cholinergic neuromuscular junction, since massive nonquantal release was shown also at the glutamatergic neuromuscular junction of the blowfly larvae (Antonov and Magazanik 1988) and in calyx-bearing fibers of the turtle ampula posterior crista (Holt et al. 2007). Similar transmitter release ("tonic" release) mediated by a transporter was also described in certain brain GABAergic synapses playing the role in perinatal changes of GABA-A receptors from excitatory to inhibitory mode (for review see Ben-Ari et al. 2007).

In adult vertebrates, some of the ACh released from the nerve terminal might escape hydrolysis by $\mathrm{AChE}$ if it is released perisynaptically, and might then act as a "local hormone" on more remote parts of muscle fibres, for example, activating the electrogenic $\mathrm{Na}^{+} / \mathrm{K}^{+}$pump. It can also change the degree of synchronization of quanta released by the nerve stimulation (Samigullin et al. 2003). Non-quantal ACh release can also alter the ovalbumin-induced functional properties of postjunctional $\mathrm{ACh}$ receptors and contribute to the disturbance of carbachol-induced contractility of skeletal muscles as reported recently by Teplov et al. (2009).

Another reason for why the vast synthesis and release of $\mathrm{ACh}$ is not directly involved in impulse transmission was put forward by one of us (E.N.) who believes that release and hydrolysis of ACh in the cleft, together with the quick uptake of the newly produced choline, keeps the synthetic machinery within the terminal ready for prompt fulfillment of different physiological demands when quantal release is augmented for example during exhaustive physical work.

Note added in the proof: Non-quantal release of $\mathrm{ACh}$ has also been reported in the rat heart. (Abramochkin DV, Nurullin LF, Borodinova AA, Tarasova NV, Sukhova GS, Nikolsky EE, Rosenshtraukh LV. Non-quantal release of acetylcholine from parasympathetic nerve terminals in the right atrium of rat. Exp Physiol. 2009 Sep 18. [Epub ahead of print])

\section{Conflict of Interest}

There is no conflict of interest.

\section{Acknowledgements}

The authors are grateful to Professor Charles Edwards, University of Tampa, FL, U.S.A., for his helpful comments, and they gratefully acknowledge the support of the GAAV IAA500110905 and AVOZ 50110509 (F.V.), Russian Foundation for Basic Research (projects nos. 07-04-01656 and 08-04-00923), programs of the President of the Russian Federation (Science School No. 4177.2008.4 and Young PhD No. 1238.2008.4) and Russian Science Support Foundation.

\footnotetext{
Abreviations

ACh - acetylcholine, AChE - acetylcholinesterase, anti-AChE - anticholinesterase, $\alpha \mathrm{BGT}-\alpha$-bungarotoxin, cGMP - cyclic guanosine monophosphate, EPD - early postdenervation depolarization, Glu - glutamate, NAAG - N-acetylaspartylglutamate, NQR - non-quantal release, $\operatorname{MEPP}(s)$ - miniature endplate potential(s), MEPC(s) miniature endplate current(s), NO - nitric oxide, NMDA - N-methyl-D-aspartate, RMP(s) - resting membrane potential(s), TC - (+)-tubocurarine, VAChT - vesicular ACh transporter.
}

\section{References}

ANDERSON DC, KING SC, PARSONS SM: Proton gradient linkage to active uptake of $\left[{ }^{3} \mathrm{H}\right]$ acetylcholine by Torpedo electric organ synaptic vesicles. Biochemistry 21: 3037-3043, 1982.

ANDERSON DC, KING SC, PARSONS SM: Inhibition of $\left[{ }^{3} \mathrm{H}\right]$ acetylcholine active transport by tetraphenylborate and other anions. Mol Pharmacol 24: 55-59, $1983 \mathrm{a}$.

ANDERSON DC, KING SC, PARSONS SM: Pharmacological characterization of the acetylcholine transport system in purified Torpedo electric organ synaptic vesicles. Mol Pharmacol 24: 48-54, 1983 b. 
ANTONOV SM, MAGAZANIK LG: Intense non-quantal release of glutamate in an insect neuromuscular junction. Neurosci Lett 93: 204-208, 1988.

ASHIHARA T, TRAYANOVA NA: Cell and tissue responses to electric shocks. Europace 7 (Suppl 2): 155-165, 2005.

AUGUSTINSSON K-B: Cholinesterases. A study in comparative enzymology. Acta Physiol Scand 15 (Suppl 52): 1-182, 1948.

BEAM KG, CALDWELL JH, CAMPBELL DT: Na channels in skeletal muscle concentrated near the neuromuscular junction. Nature 313: 588-590, 1985.

BEN-ARI Y, GAIARSA JL, TYZIO R, KHAZIPOV R: GABA: a pioneer transmitter that excites immature neurons and generates primitive oscillations. Physiol Rev 87: 1215-1284, 2007.

BENOIT P, CHANGEUX JP: Consequences of tenotomy on the evolution of multiinnervation in developing rat soleus muscle. Brain Res 99: 354-358, 1975.

BERGER UV, CARTER RE, COYLE JT: The immunocytochemical localization of N-acetylaspartyl glutamate, its hydrolysing enzyme NAALADase, and the NMDAR-1 receptor at a vertebrate neuromuscular junction. Neurosci 64: 847-850, 1995.

BETZ WJ, CALDWELL JH, KINNAMON SC: Increased sodium conductance in the synaptic region of rat skeletal muscle fibres. $J$ Physiol Lond 352: 189-202, 1984.

BLAKELY RD, ROBINSON MB, THOMPSON RC, COYLE JT: Hydrolysis of the brain dipeptide N-acetyl-L-aspartylL-glutamate: subcellular and regional distribution, ontogeny, and the effect of lesions on N-acetylated-alphalinked acidic dipeptidase activity. $J$ Neurochem 50: 1200-1209, 1988.

BRAY JJ, HAWKEN MJ, HUBBARD JI, POCKETT S, WILSON L: The membrane potential of rat diaphragm muscle fibres and the effect of denervation. $J$ Physiol Lond 255: 651-667, 1976.

BRAY JJ, FORREST JW, HUBBARD JI: Evidence for the role of non-quantal acetylcholine in the maintenance of the membrane potential of rat skeletal muscle. J Physiol Lond 326: 285-296, 1982.

BRENNER HR: Dependence of acetylcholine receptor channel conversion on muscle activity at denervated neonatal rat endplates. Neurosci Lett 88: 161-166, 1988.

BROWN MC, JANSEN JK, VAN ESSEN D: Polyneuronal innervation of skeletal muscle in new-born rats and its elimination during maturation. J Physiol Lond 261: 387-422, 1976.

BUKHARAEVA EA, SALAKHUTDINOV RI, VYSKOČIL F, NIKOLSKY EE: Spontaneous quantal and non-quantal release of acetylcholine at mouse endplate during onset of hypoxia. Physiol Res 54: 251-255, 2005.

BURNSTOCK G: Physiology and pathophysiology of purinergic neurotransmission. Physiol Rev 87: 659-797, 2007.

CALDWELL JH, BETZ WJ: Properties of an endogenous steady current in rat muscle. J Gen Physiol 83: 157-173, 1984.

CARVELLI L, BLAKELY RD, DEFELICE LJ: Dopamine transporter/syntaxin 1A interactions regulate transporter channel activity and dopaminergic synaptic transmission. Proc Natl Acad Sci USA 105: 14192-14197, 2008.

CASSIDY M, NEALE JH: N-acetylaspartylglutamate catabolism is achieved by an enzyme on the cell surface of neurons and glia. Neuropeptides 24: 271-278, 1993.

CIANI S, EDWARDS C: The effect of acetylcholine on neuromuscular transmission in the frog. J Pharmacol Exp Ther 142: 21-23, 1963.

CONNOLD AL, EVERS JV, VRBOVA G: Effect of low calcium and protease inhibitors on synapse elimination during postnatal development in rat soleus muscle. Dev Brain Res 28: 99-107, 1986.

CUNHA RA, SEBASTIAO AM: Adenosine and adenine nucleotides are independently released from both the nerve terminals and the muscle fibres upon electrical stimulation of the innervated skeletal muscle of the frog. Pflügers Arch 424: 503-510, 1993.

DLOUHÁ H, TEISINGER J, VYSKOČIL F: Activation of membrane $\mathrm{Na}^{+} / \mathrm{K}^{+}$-ATPase of mouse skeletal muscle by acetylcholine and its inhibition by alpha-bungarotoxin, curare and atropine. Pflügers Arch 380: 101-104, 1979.

DLOUHÁ H, DONSELAAR Y, TEISINGER J, VYSKOČIL F: Effect of temperature and ouabain on th $\mathrm{Na}^{+}-\mathrm{K}^{+}$activated membrane ATPase and electrogenic ionic pump of the golden hamster and mouse diaphragm. Physiol Bohemoslov 29: 543-552, 1980.

DOIA M, IWASAKIB K: $\mathrm{Na}^{+} / \mathrm{K}^{+}$ATPase regulates the expression and localization of acetylcholine receptors in a pump activity-independent manner. Mol Cell Neurosci 38: 548-558, 2008.

DOLEŽAL V, TUČEK S: The synthesis and release of acetylcholine in normal and denervated rat diaphragms during incubation in vitro. J Physiol Lond 334: 461-474, 1983. 
DOLEŽAL V, TUČEK S: Effects of tetrodotoxin, $\mathrm{Ca}^{2+}$ absence, d-tubocurarine and vesamicol on spontaneous acetylcholine release from rat muscle. J Physiol Lond 458: 1-9, 1992.

DOLEŽAL V, VYSKOČIL F, TUČEK S: Decrease of the spontaneous non-quantal release of acetylcholine from the phrenic nerve in botulinum-poisoned rat diaphragm. Pflügers Arch 397: 319-322, 1983.

DOUGLAS WW, PATON WD: The mechanisms of motor end-plate depolarization due to a cholinesterase-inhibiting drug. J Physiol Lond 124: 325-344, 1954.

DUXSON MJ: The effect of postsynaptic block on development of the neuromuscular junction in postnatal rats. J Neurocytol 11: 395-408, 1982.

DUXSON MJ, VRBOVÁ G: Inhibition of acetylcholinesterase accelerates axon terminal withdrawal at the developing rat neuromuscular junction. J Neurocytol 14: 337-363, 1985.

ECOBICHON DJ, ISRAEL Y: Characterization of the esterases from electric tissue of Electrophorus by starch-gel electrophoresis. Can J Biochem 45: 1099-1105, 1967.

EDWARDS C: The selectivity of ion channels in nerve and muscle. Neuroscience 7: 1335-1366, 1982.

EDWARDS C, VYSKOČIL F: The effects of the replacement of $\mathrm{K}^{+}$by $\mathrm{Tl}^{+}, \mathrm{Rb}^{+}$, and $\mathrm{NH}_{4}^{+}$on the muscle membrane potential. Gen Physiol Biophys 3: 259-264, 1984.

EDWARDS C, DOLEŽAL V, TUČEK S, ZEMKOVÁ H, VYSKOČIL F: Is an acetylcholine transport system responsible for non-quantal release of acetylcholine at the rodent myoneural junction? Proc Natl Acad Sci USA 82: 3514$3518,1985$.

EDWARDS FA, GIBB AJ: ATP - a fast neurotransmitter. FEBS Lett 325: 86-89, 1993.

ELFMAN L, HEILBRONN E, JORGENSEN PL: Fractionation of protein components of plasma membranes from the electric organ of Torpedo marmorata. Biochim Biophys Acta 693: 273-279, 1982.

FELTZ A, TRAUTMANN A: Interaction between nerve-related acetylcholine and bath applied agonists at the frog endplate. J Physiol Lond 299: 533-552, 1980.

FERGUSON SM, SAVCHENKO V, APPARSUNDARAM S, ZWICK M, WRIGHT J, HEILMAN CJ, YI H, LEVEY AI, BLAKELY RD: Vesicular localization and activity-dependent trafficking of presynaptic choline transporters. J Neurosci 23: 9697-9709, 2003.

FLETCHER P, FORRESTER T: The effect of curare on the release of acetylcholine from mammalian motor nerve terminals and an estimate of quantum content. J Physiol Lond 251: 131-144, 1975.

FU W-M, LIU JJ: Regulation of acetylcholine release by presynaptic nicotinic receptors at developing neuromuscular synapses. Mol Pharmacol 51: 390-398, 1997.

FU W-M, LIOU H-C, CHEN Y-H WANG S-M: Release of acetylcholine from embryonic myocytes in Xenopus cell cultures. J Physiol Lond 509: 497-506, 1998.

GALKIN AV, GINIATULLIN RA, MUKHTAROV MR, SVANDOVÁ I, GRISHIN SN, VYSKOČIL F: ATP but not adenosine inhibits nonquantal acetylcholine release at the mouse neuromuscular junction. Eur $J$ Neurosci 13: 2047-2053, 2001.

GINIATULLIN RA, KHAMITOV G, KHAZIPOV R, MAGAZANIK LG, NIKOLSKY EE, SNETKOV VA, VYSKOČIL F: Development of desensitization during repetitive end-plate activity and single end-plate currents in frog muscle. J Physiol Lond 412: 113-122, 1989.

GINIATULLIN RA, KHAZIPOV RN, ORANSKA TI, NIKOLSKY EE, VORONIN VA, VYSKOČIL F: The effect of non-quantal acetylcholine release on quantal miniature currents at mouse diaphragm. J Physiol Lond 466: 105 $114,1993$.

GINIATULLIN RA, SOKOLOVA EM: ATP and adenosine inhibit transmitter release at the frog neuromuscular junction through distinct presynaptic receptors. Br J Pharmacol 124: 839-844, 1998.

GIROD R, POPOV S, ALDER J, ZHENG JQ, LOHOF A, POO MM: Spontaneous quantal transmitter secretion from myocytes and fibroblasts: comparison with neuronal secretion. J Neurosci 15: 2826-2838, 1995.

GREENSMITH L, VRBOVÁ G: Neuromuscular contacts in the developing rat soleus depend on muscle activity. Dev Brain Res 62: 121-129, 1991.

GRINNELL AD, GUNDERSEN CB, MERINEY SD, YOUNG SH: Direct measurement of ACh release from exposed frog nerve terminals: constraints on interpretation of non-quantal release. J Physiol Lond 419: 225-251, 1989.

GROZDANOVIC Z, GOSSRAU R: Co-localization of nitric oxide synthase I (NOS I) and NMDA receptor subunit 1 (NMDAR-1) at the neuromuscular junction in rat and mouse skeletal muscle. Cell Tissue Res 291: 57-63, 1998. 
HAIMANN C, TORRI-TARELLI F, FESCE R, CECCARELLI B: Measurement of quantal secretion induced by ouabain and its correlation with depletion of synaptic vesicles. J Cell Biol 101: 1953-1965, 1985.

HAIMOVICH B, SCHOTLAND DL, FIELES WE, BARCHI RL: Localization of sodium channel subtypes in adult rat skeletal muscle using channel-specific monoclonal antibodies. J Neurosci 9: 2957-2966, 1987.

HARTZELL HC, KUFFLER SW, YOSHIAMI D: Postsynaptic potentiation: interaction between quanta of acetylcholine at the skeletal neuromuscular synapse. J Physiol Lond 251: 427-463, 1975.

HE L, WU LG: The debate on the kiss-and-run fusion at synapses. Trends Neurosci 30: 447-455, 2007.

HOLT JC, CHATLANI S, LYSAKOWSKI A, GOLDBERG JM: Quantal and nonquantal transmission in calyx-bearing fibers of the turtle posterior crista. J Neurophysiol 98: 1083-1011, 2007.

HUANG CF, NEVILLE CM, SCHMIDT J: Control of myogenic factor genes by the membrane depolarization/protein kinase C cascade in chick skeletal muscle. FEBS Lett 319: 21-25, 1993.

IJKEMA-PAASSEN J, GRAMSBERGEN A: Development of postural muscles and their innervation. Neural Plast 12: 141-151, 2005.

ISRAËL M, LESBATS B, MEUNIER FM, STINNAKRE J: Postsynaptic release of adenosine triphosphate induced by single impulse transmitter action. Proc R Soc Lond B Biol Sci 193: 461-468, 1976.

JACKSON MB: Single channel currents in the nicotinic acetylcholine receptor: a direct demonstration of allosteric transitions. Trends Biochem Sci 19: 396-399, 1994.

KATZ B, MILEDI R: Transmitter leakage from motor nerve endings. Proc R Soc Lond B Biol Sci 196: 59-72, 1977.

KOVYAZINA IV, NIKOLSKY EE, GINIATULLIN RA, ADÁMEK S, VYSKOČIL F: Dependence of miniature endplate current on kinetic parameters of acetylcholine receptors activation: a model study. Neurochem Res $\mathbf{2 8}$ : 443-448, 2003.

KRNJEVIC K, STRAUGHAN DW: The release of acetylcholine from the denervated rat diaphragm. J Physiol Lond 170: 371-378, 1964.

KUFFLER SW, YOSHIKAMI D: The number of transmitter molecules in a quantum: an estimate from iontophoretic application of acetylcholine at the neuromuscular synapse. J Physiol Lond 251: 465-482, 1975.

LI J, KING NC, SINOWAY LI: ATP concentrations and muscle tension increase linearly with muscle contraction. $J$ Appl Physiol 95: 577-583, 2003.

LI J, GAO Z, KEHOE V, XING J, KING N, SINOWAY L: Interstitial adenosine triphosphate modulates muscle afferent nerve-mediated pressor reflex. Muscle Nerve 38: 972-977, 2008.

LÜCK G, HOCH W, HOPF C, BLOTTNER W: Nitric oxide synthase (NOS-1) coclustered with agrin-induced AchRspecializations on cultured skeletal myotubes. Mol Cell Neurosci 16: 269-281, 2000.

LUPA M, KRZEMIEN DM, SCHALLER KL, CALDWELL JH: Aggregation of sodium channels during development and maturation of the neuromuscular junction. J Neurosci 13: 1326-1336, 1993.

LUPA MT, TABTI N, THESLEFF S, VYSKOČIL F, YU SP: The nature and origin of calcium-insensitive miniature endplate potentials at rodent neuromuscular junctions. J Physiol Lond 381: 607-618, 1986.

MALOMOUZH AI, MUKHTAROV MR, NIKOLSKY EE, VYSKOČIL F, LIEBERMAN EM, URAZAEV A: Glutamate regulation of non-quantal release of acetylcholine in the rat neuromuscular junction. $J$ Neurochem $\mathbf{8 5}$ : 206-213, 2003.

MALOMOUZH AI, NIKOLSKY EE, LIEBERMAN EM, SHERMAN JA, LUBISCHER JL, GROSSFELD RM, URAZAEV AK: Effect of N-acetylaspartylglutamate (NAAG) on non-quantal and spontaneous quantal release of acetylcholine at the neuromuscular synapse of rat. J Neurochem 94: 257-265, 2005.

MALOMOUZH AI, MUKHTAROV MR, NIKOLSKY EE, VYSKOČIL F: Muscarinic M1 acetylcholine receptors regulate the non-quantal release of acetylcholine in the rat neuromuscular junction via NO-dependent mechanism. J Neurochem 102: 2110-2117, 2007.

MARASTONI S, LIGRESTI G, LORENZON E, COLOMBATTI A, MONGIAT M: Extracellular matrix: a matter of life and death. Connect Tissue Res 49: 203-206, 2008.

MARSHALL MW, WARD MR: Anode break excitation in denervated rat skeletal muscle fibres. J Physiol Lond 236: 413420, 1974.

MARTIN AR, LEVINSON SR: Contribution of the $\mathrm{Na}^{+}-\mathrm{K}^{+}$pump to membrane potential in familial periodic paralysis. Muscle Nerve 8: 359-362, 1985. 
MATSUOKA I, ZHOU Q, ISHIMOTO H, NAKANISHI H: Extracellular ATP stimulates adenylyl cyclase and phospholipase C through distinct purinoceptors in NG108-15 cells. Mol Pharmacol 47: 855-862, 1995.

MEISTER B, ARVIDSSON U, ZHANG X, JACOBSSON G, VILLAR MJ, HOKFELT T: Glutamate transporter mRNA and glutamate-like immunoreactivity in spinal motoneurones. Neuroreport 5: 337-340, 1993.

MERINEY SD, YOUNG SH, GRINNELL AD: Constraints on the interpretation of nonquantal acetylcholine release from frog neuromuscular junctions. Proc Natl Acad Sci USA 86: 2098-2102, 1989.

MINIC J, MOLGO J, KARLSSON E, KREJCI E: Regulation of acetylcholine release by muscarinic receptors at the mouse neuromuscular junction depends on the activity of acetylcholinesterase. Eur J Neurosci 15: 439-448, 2002.

MITCHELL JF, SILVER A: The spontaneous release of acetylcholine from the denervated hemidiaphragm of the rat. J Physiol Lond 165: 117-129, 1963.

MOFFETT JR, WILLIAMSON L, PALKOVITS M, NAMBOODIRI MA: N-acetylaspartylglutamate: a transmitter candidate for the retinohypothalamic tract. Proc Natl Acad Sci USA 87: 8065-8069, 1990.

MOLENAAR PC, POLAK RL: Acetylcholine synthesizing enzymes in frog skeletal muscle. J Neurochem 35: 1021-1025, 1980.

MOLINAR-RODE R, PASIK P: Amino acids and N-acetyl-aspartyl-glutamate as neurotransmitter candidates in the monkey retinogeniculate pathways. Exp Brain Res 89: 40-48, 1992.

MORAVEC J, VYSKOČIL F: Early postdenervation depolarization develops faster at endplates of hibernating golden hamsters where spontaneous quantal and non-quantal acetylcholine release is very small. Neurosci Res 51: 25-29, 2005.

MUKHTAROV MR, VYSKOČIL F, URAZAEV AK, NIKOLSKY EE: Non-quantal acetylcholine release is increased after nitric oxide synthase inhibition. Physiol Res 48: 315-317, 1999.

MUKHTAROV MR, URAZAEV AKH, NIKOLSKY EE, VYSKOČIL F: Effect of nitric oxide and NO synthase inhibition on nonquantal acetylcholine release in the rat diaphragm. Eur J Neurosci 12: 980-986, 2000.

NEALE JH, BZDEGA T, WROBLEWSKA B: N-Acetylaspartylglutamate: the most abundant peptide neurotransmitter in the mammalian central nervous system. $J$ Neurochem 75: 443-452, 2000.

NIKOLSKY EE, VORONIN VA: Temperature dependence of spontaneous quantal and nonquantal transmitter release from motor nerve terminals in mice. (in Russian) Neurofiziologia 18: 361-367, 1986.

NIKOLSKY EE, VORONIN VA, ORANSKA TI, VYSKOČIL F: The dependence of non-quantal acetylcholine release on the choline-uptake system in the mouse diaphragm. Pflügers Arch 418: 74-78, $1991 \mathrm{a}$.

NIKOLSKY EE, VORONIN VA, VYSKOČIL F: Kinetic differences in the effect of calcium on quantal and non-quantal acetylcholine release at the murine diaphragm. Neurosci Lett 123: 192-194, $1991 \mathrm{~b}$.

NIKOLSKY EE, ORANSKA TI, VYSKOČIL F: Non-quantal acetylcholine release after cholinesterase inhibition in vivo. Physiol Res 41: 333-334, 1992.

NIKOLSKY EE, ZEMKOVÁ H, VORONIN VA, VYSKOČIL F: Role of non-quantal acetylcholine release in surplus polarization of mouse diaphragm fibres at the endplate zone. J Physiol Lond 477: 497-502, 1994.

NIKOLSKY EE, ORANSKA TI, VYSKOČIL F: Non-quantal acetylcholine release in the mouse diaphragm after phrenic nerve crush and during recovery. Exp Physiol 81: 341-348, 1996.

NIKOLSKY EE, VYSKOČIL F, BUKHARAEVA EA, SAMIGULLIN D, MAGAZANIK LG: Cholinergic regulation of the evoked quantal release at frog neuromuscular junction. $J$ Physiol Lond 560: 77-88, 2004.

NISHIMARU H, RESTREPO CE, RYGE J, YANAGAWA Y, KIEHN O: Mammalian motor neurons corelease glutamate and acetylcholine at central synapses. Proc Natl Acad Sci USA 102: 5245-5249, 2005.

O'BRIEN RA, OSTBERG AJ, VRBOVÁ G: Observations on the elimination of polyneuronal innervation in developing mammalian skeletal muscle. J Physiol 282: 571-582, 1978.

O'BRIEN RA, OSTBERG AJ, VRBOVÁ G: The effect of acetylcholine on the function and structure of the developing mammalian neuromuscular junction. Neuroscience 5: 1367-1379, 1980.

O'BRIEN RA, OSTBERG AJ, VRBOVÁ G: Protease inhibitors reduce the loss of nerve terminals induced by activity and calcium in developing rat soleus muscles in vitro. Neuroscience 12: 637-646, 1984.

OHTANI Y, MINAMI M, SATOH M: Expression of inducible nitric oxide synthase mRNA and production of nitric oxide are induced by adenosine triphosphate in cultured rat microglia. Neurosci Lett 293: 72-74, 2000. 
OLIVEIRA L, TIMÓTEO MA, CORREIA-DE-SÁ P: Modulation by adenosine of both muscarinic $\mathrm{M}_{1}$-facilitation and $\mathrm{M}_{2}$-inhibition of $\left[{ }^{3} \mathrm{H}\right]$-acetylcholine release from the rat motor nerve terminals. Eur $J$ Neurosci 15: 1728-1736, 2002.

PANKRATOV Y, LALO U, VERKHRATSKY A, NORTH RA: Vesicular release of ATP at central synapses. Pflügers Arch 452: 589-597, 2006.

PARSONS SM, KOENIGSBERGER R: Specific stimulated uptake of acetylcholine by Torpedo electric organ synaptic vesicles. Proc Natl Acad Sci USA 77: 6234-6238, 1980.

PETROV AM, GINIATULLIN AR, SITDIKOVA GF, ZEFIROV AL: The role of cGMP-dependent signaling pathway in synaptic vesicle cycle at the frog motor nerve terminals. J Neurosci 28: 13216-13222, 2008.

PINARD A, LEVESQUE S, VALLEE J, ROBITAILLE R: Glutamatergic modulation of synaptic plasticity at a PNS vertebrate cholinergic synapse. Eur J Neurosci 18: 3241-3250, 2003.

PINSKER H, KANDEL ER: Synaptic activation of an electrogenic sodium pump. Science 163: 931-934, 1969.

POTTER LT: Synthesis, storage and release of $\left[{ }^{14} \mathrm{C}\right]$ acetylcholine in isolated rat diaphragm muscles. $J$ Physiol Lond 206: 145-166, 1970.

REDFERN PA: Neuromuscular transmission in new-born rats. J Physiol Lond 209: 701-709, 1970.

RIBEIRO AJ, CUNHA RA, CORREIA-DE-SA P, SEBASTIAO AM: Purinergic regulation of acetylcholine release. Prog Brain Res 109: 231-241, 1996.

SAITO H, THAPALIYA S, MATSUYAMA H, NISHIMURA M, TAKEWAKI T: Enhancement of ATP release in hindlimb sympathetic perivascular nerve of the golden hamster during hibernation. J Physiol Lond 531: 495-507, 2001.

SAMIGULLIN D, BUKHARAEVA EA, NIKOLSKY E, ADÁMEK S, VYSKOČIL F: Long release latencies are increased by acetylcholine at frog endplate. Physiol Res 52: 475-480, 2003.

SANABRIA ER, WOZNIAK KM, SLUSHER BS, KELLER A: GCP II (NAALADase) inhibition suppresses mossy fiber-CA3 synaptic neurotransmission by a presynaptic mechanism. J Neurophysiol 91: 182-193, 2004.

SANTAFÉ MM, LANUZA MA, GARCIA N, TOMÀS J: Muscarinic autoreceptors modulate transmitter release through protein kinase $\mathrm{C}$ and protein kinase A in the rat motor nerve terminal. Eur J Neurosci 23: 2048-2056, 2006.

SANTAFÉ MM, SALON I, GARCIA N, LANUZA MA, UCHITEL OD, TOMÀS J: Modulation of ACh release by presynaptic muscarinic autoreceptors in the neuromuscular junction of the newborn and adult rat. Eur J Neurosci 17: 119-127, 2003.

SANTOS DA, SALGADO AI, CUNHA RA: ATP is released from nerve terminals and from activated muscle fibres on stimulation of the rat phrenic nerve. Neurosci Lett 338: 225-228, 2003.

SEKIGUCHI M, WADA K, WENTHOLD RJ: N-acetylaspartylglutamate acts as an agonist upon homomeric NMDA receptor (NMDAR-1) expressed in Xenopus oocytes. FEBS Lett 311: 285-289, 1992.

SHAKIRYANOVA DM, ZEFIROV AL, NIKOLSKY EE, VYSKOČIL F: The effect of acetylcholine and related drugs on currents at the frog motor nerve terminal. Eur J Pharmacol 263: 107-114, 1994.

SHIH YL: Abolishment of non-quantal release of acetylcholine from the mouse phrenic nerve endings by toosendanin. Jpn J Physiol 36: 601-605, 1986.

SILINSKY EM, REDMAN RS: Synchronous release of ATP and neurotransmitter within milliseconds of a motor nerve impulse in the frog. J Physiol Lond 492: 815-822, 1996.

SLATER CR: Structural factors influencing the efficacy of neuromuscular transmission. Ann NY Acad Sci 1132: 1-12, 2008.

SLUTSKY I, PARNAS H, PARNAS I: Presynaptic effects of muscarine on ACh release at the frog neuromuscular junction. J Physiol Lond 514: 769-782, 1999.

SLUTSKY I, SILMAN I, PARNAS I, PARNAS H: Presynaptic $\mathrm{M}_{2}$ muscarinic receptors are involved in controlling the kinetics of ACh release at the frog neuromuscular junction. J Physiol Lond 536: 717-725, 2001.

SMITH DO: Sources of adenosine released during neuromuscular transmission in the rat. J Physiol Lond 432: 343-354, 1991.

SOKOLOVA E, GRISHIN S, SHAKIRZYANOVA A, TALANTOVA M, GINIATULLIN R: Distinct receptors and different transduction mechanisms for ATP and adenosine at the frog motor nerve endings. Eur J Neurosci 18: 1254-1264, 2003. 
SPRATT DE, TAIAKINA V, GUILLEMETTE JG: Calcium-deficient calmodulin binding and activation of neuronal and inducible nitric oxide synthases. Biochim Biophys Acta 1774: 1351-1358, 2007.

SUN Y-A, POO M-M: Non-quantal release of acetylcholine at a developing neuromuscular synapse in culture. $J$ Neurosci 5: 634-642, 1985.

ŠVANDOVÁ I, VYSKOČIL F, UJEC E: Nitric oxide synthase inhibition partially imitates postdenervation tetrodotoxin resistance and anodal break excitation in innervated rat muscles. Physiol Res 50: P29, 2001.

TAYLOR P: The cholinesterases. J Biol Chem 266: 4025-4028, 1991.

TEPLOV AY, GRISHIN SN, MUKHAMEDYAROV MA, ZIGANSHIN AU, ZEFIROV AL, PALOTÁS A: Ovalbumininduced sensitization affects non-quantal acetylcholine release from motor nerve terminals and alters contractility of skeletal muscles in mice. Exp Physiol 94: 264-268, 2009.

THESLEFF S, VYSKOČIL F, WARD MR: The action potential in end-plate and extrajunctional regions of rat skeletal muscle. Acta Physiol Scand 91: 196-202, 1974.

THOMPSON W, KUFFLER DP, JANSEN JK: The effect of prolonged, reversible block of nerve impulses on the elimination of polyneuronal innervation of new-born rat skeletal muscle fibers. Neuroscience 4: 271-281, 1979.

TIMÓTEO MA, OLIVEIRA L, CAMPESATTO-MELLA E, BARROSO A, SILVA C, MAGALHÃES-CARDOSO MT, ALVES-DO-PRADO W, CORREIA-DE-SÁ P: Tuning adenosine $\mathrm{A}_{1}$ and $\mathrm{A}_{2 \mathrm{~A}}$ receptors activation mediates Lcitrulline-induced inhibition of $\left[{ }^{3} \mathrm{H}\right]$-acetylcholine release depending on nerve stimulation pattern. Neurochem Int 52: 834-845, 2008.

TSAI G, FORLONI G, ROBINSON MB, STAUCH BL, COYLE JT: Calcium-dependent evoked release of N-[ $\left.{ }^{3} \mathrm{H}\right]$ acetylaspartylglutamate from the optic pathway. J Neurochem 51: 1956-1959, 1988.

TUČEK S: The synthesis of acetylcholine in skeletal muscles of the rat. $J$ Physiol Lond 322: 53-69, 1982.

URAZAEV A, MAGSUMOV ST, POLETAYEV GI, NIKOLSKY EE, VYSKOČIL F: Muscle NMDA receptors regulate the resting membrane potential through NO-synthase. Physiol Res 44: 205-208, 1995.

URAZAEV A, NAUMENKO NV, POLETAYEV GI, NIKOLSKY EE, VYSKOČIL F: Acetylcholine and carbachol prevent muscle depolarization in denervated rat diaphragm. Neuroreport 8: 403-406, 1997.

URAZAEV AKH, NAUMENKO NV, POLETAYEV GI, NIKOLSKY EE, VYSKOČIL F: The effect of glutamate and inhibitors of NMDA receptors on postdenervation decrease of membrane potential in rat diaphragm. Mol Chem Neuropathol 33: 163-674, 1998.

URAZAEV A, NAUMENKO NV, NIKOLSKY EE, VYSKOČIL F: The glutamate and carbachol effects on the early post-denervation depolarization in rat diaphragm are directed towards furosemide-sensitive chloride transport. Neurosci Res 33: 81-86, 1999.

URAZAEV A, NAUMENKO N, MALOMOUGH A, NIKOLSKY E, VYSKOČIL F: Carbachol and acetylcholine delay the early postdenervation depolarization of muscle fibres through $\mathrm{M}_{1}$-cholinergic receptors. Neurosci Res 37: 255263,2000 .

VALIVULLAH HM, LANCASTER J, SWEETNAM PM, NEALE JH: Interactions between N-acetylaspartylglutamate and AMPA, kainate, and NMDA binding sites. J Neurochem 63: 1714-1719, 1994.

VAN DER KLOOT W: Loading and recycling of synaptic vesicles in the Torpedo electric organ and the vertebrate neuromuscular junction. Prog Neurobiol 71: 269-303, 2003.

VIZI ES, VYSKOČIL F: Changes in total and quantal release of acetylcholine in the mouse diaphragm during activation and inhibition of membrane ATPase. J Physiol Lond 286: 1-14, 1979.

VYAS S, BRADFORD HF: Co-release of acetylcholine, glutamate and taurine from synaptosomes of Torpedo electric organ. Neurosci Lett 82: 58-64, 1987.

VYSKOČIL F: Action potentials of the rat diaphragm and their sensitivity to tetrodotoxin during postnatal development and old age. Pflügers Arch 352: 155-163, 1974.

VYSKOČIL F: The regulatory role of membrane $\mathrm{Na}^{+}-\mathrm{K}^{+}$-ATPase in non-quantal release of transmitter at the neuromuscular junction. In: The Cholinergic Synapse, S TUČEK (ed), Elsevier, New York, 1978, pp 183-190.

VYSKOČIL F: The regulatory role of membrane $\mathrm{Na}^{+}-\mathrm{K}^{+}$-ATPase in non-quantal release of transmitter at the neuromuscular junction. Prog Brain Res 49: 183-189, 1979.

VYSKOČIL F: Inhibition of non-quantal acetylcholine leakage by 2(4-phenylpiperidine) cyclohexanol in the mouse diaphragm. Neurosci Lett 59: 277-280, 1985. 
VYSKOČIL F: Early postdenervation depolarization is controlled by acetylcholine and glutamate via nitric oxide regulation of the chloride transporter. Neurochem Res 28: 575-585, 2003.

VYSKOČIL F: The effect of atropine and diazepam on the mammalian neuromuscular junction. (in Czech) $\check{C} s$ fyziol $\mathbf{5 5}$ : 111-114, 2006.

VYSKOČIL F, ILLÉS P: Non-quantal release of transmitter at mouse neuromuscular junction and its dependence on the activity of $\mathrm{Na}^{+}-\mathrm{K}^{+}$ATP-ase. Pflügers Arch 370: 295-297, 1977.

VYSKOČIL F, ILLÉS P: Electrophysiological examination of transmitter release in non-quantal form in the mouse diaphragm and the activity of membrane ATP-ase. Physiol Bohemoslov 27: 449-455, 1978.

VYSKOČIL F, MAGAZANIK LG: Dual end-plate potentials at the single neuromuscular junction of the adult frog. Pflügers Arch 368: 271-273, 1977.

VYSKOČIL F, VRBOVÁ G: Non-quantal release of acetylcholine affects polyneuronal innervation on developing rat muscle fibres. Eur J Neurosci 5: 1677-1683, 1993.

VYSKOČIL F, NIKOLSKY E, EDWARDS C: An analysis of the mechanisms underlying the non-quantal release of acetylcholine at the mouse neuromuscular junction. Neuroscience 9: 429-435, 1983.

VYSKOČIL F, ZEMKOVÁ H, TEISINGER J, SVOBODA P: Arachidonate activates muscle electrogenic sodium pump and brain microsome $\mathrm{Na}^{+}, \mathrm{K}^{+}$-ATPase under suboptimal conditions. Brain Res 436: 85-91, 1987a.

VYSKOČIL P, ZEMKOVÁ H, TEISINGER J, VYSKOČIL F: Arachidonate has a positive effect on the electrogenic sodium-potassium pump in the mouse diaphragm. Physiol Bohemoslov 36: 167-169, $1987 \mathrm{~b}$.

VYSKOČIL F, ZEMKOVÁ H, EDWARDS C: Non-quantal acetylcholine release. In: Neuromuscular Junction, LC SELLIN, R LIBELIUS, STHESLEFF (eds), Elsevier, Amsterdam, 1989, pp 197-205.

VYSKOČIL F, NIKOLSKY EE, ZEMKOVÁ H, KRŮŠEK J: The role of non-quantal release of acetylcholine in regulation of postsynaptic membrane electrogenesis. J Physiol Lond 89: 157-162, 1995.

WAERHAUG O, OTTERSEN OP: Demonstration of glutamate-like immunoreactivity at rat neuromuscular junctions by quantitative electron microscopic immunocytochemistry. Anat Embryol 188: 501-513, 1993.

WESSLER I, DIENER A, OFFERMANN M: Facilitatory and inhibitory muscarine receptors on the rat phrenic nerve: effects of pirenzepine and dicyclomine. Naunyn-Schmiedebergs Arch Pharmacol 338: 138-142, 1988.

WESTBROOK GL, MAYER ML, NAMBOODIRI MA, NEALE JH: High concentrations of N-acetylaspartylglutamate (NAAG) selectively activate NMDA receptors on mouse spinal cord neurons in cell culture. J Neurosci 6: 3385 3392, 1986.

WROBLEWSKA B, WROBLEWSKI JT, PSHENICHKIN S, SURIN A, SULLIVAN SE, NEALE JH: $\mathrm{N}$-acetylaspartylglutamate selectively activates mGluR3 receptors in transfected cells. $J$ Neurochem 69: 174-181, 1997.

YOUNG SH, POO MM: Spontaneous release of transmitter from growth cones of embryonic neurones. Nature 305: 634637, 1983.

YU SP, VAN DER KLOOT W: Non-quantal acetylcholine release at mouse neuromuscular junction: effects of elevated quantal release and aconitine. Neurosci Lett 117: 111-116, 1990.

ZELENÁ J: The effect of denervation of muscle development. In: The Denervated Muscle, E GUTMANN (ed), Czechoslovak Academy of Sciences Publishing House, Prague, 1962, pp 103-126.

ZELENÁ J, VYSKOČIL F, JIRMANOVÁ I: The elimination of polyneuronal innervation of end-plates in developing rat muscles with altered function. Prog Brain Res 49: 365-372, 1979.

ZEMKOVÁ H, VYSKOČIL F: Effect of $\mathrm{Mg}^{2+}$ on nonquantal acetylcholine release at the mouse neuromuscular junction. Neurosci Lett 103: 293-297, 1989.

ZEMKOVÁ H, VYSKOČIL F, EDWARDS C: A study on early post-denervation changes of non-quantal and quantal acetylcholine release in the rat diaphragm. Pflügers Arch 409: 540-546, 1987.

ZEMKOVÁ H, VYSKOČIL F, EDWARDS C: The effects of nerve terminal activity on non-quantal release of acetylcholine at the mouse neuromuscular junction. J Physiol Lond 423: 631-640, 1990.

ZHU P-H, VRBOVÁ G: The role $\mathrm{Ca}^{2+}$ in the elimination of polyneuronal innervation in rat fast muscle fibres. Eur $J$ Neurosci 4: 433-437, 1992. 